\title{
Polymeric carriers for enhanced delivery of probiotics
}

\author{
Asgari, Shadi; Pourjavadi, Ali; Licht, Tine Rask; Boisen, Anja; Ajalloueian, Fatemeh
}

Published in:

Advanced Drug Delivery Reviews

Link to article, DOI:

10.1016/j.addr.2020.07.014

Publication date:

2020

Document Version

Peer reviewed version

Link back to DTU Orbit

Citation (APA):

Asgari, S., Pourjavadi, A., Licht, T. R., Boisen, A., \& Ajalloueian, F. (2020). Polymeric carriers for enhanced delivery of probiotics. Advanced Drug Delivery Reviews, 161-162, 1-21.

https://doi.org/10.1016/j.addr.2020.07.014

\section{General rights}

Copyright and moral rights for the publications made accessible in the public portal are retained by the authors and/or other copyright owners and it is a condition of accessing publications that users recognise and abide by the legal requirements associated with these rights.

- Users may download and print one copy of any publication from the public portal for the purpose of private study or research.

- You may not further distribute the material or use it for any profit-making activity or commercial gain

- You may freely distribute the URL identifying the publication in the public portal

If you believe that this document breaches copyright please contact us providing details, and we will remove access to the work immediately and investigate your claim 


\section{Polymeric Carriers for Enhanced Delivery of Probiotics}

Shadi Asgari ${ }^{1,2}$, Ali Pourjavadi², Tine Rask Licht ${ }^{3}$, Anja Boisen ${ }^{1,4}$, Fatemeh

Ajalloueian $^{1,4 *}$
9

Abstract: Probiotics are live microorganisms (usually bacteria), which are defined by their 15 ability to confer health benefits to the host, if administered adequately. Probiotics are not only 16 used as health supplements but have also been applied in various attempts to prevent and treat 17 gastrointestinal (GI) and non-gastrointestinal diseases such as diarrhea, colon cancer, obesity, 18 diabetes, and inflammation. One of the challenges in the use of probiotics is putative loss of 19 viability by the time of administration. It can be due to procedures that the probiotic products 20 go through during fabrication, storage, or administration. Biocompatible and biodegradable 21 polymers with specific moieties or $\mathrm{pH} / \mathrm{enzyme}$ sensitivity have shown great potential as 22 carriers of the bacteria for 1) better viability, 2) longer storage times, 3) preservation from the 23 aggressive environment in the stomach and 4) topographically targeted delivery of probiotics. In this review, we focus on polymeric carriers and the procedures applied for encapsulation of 25 the probiotics into them. At the end, some novel methods for specific probiotic delivery, 26 possibilities to improve the targeted delivery of probiotics and some challenges are discussed.

.

6


Keywords: Probiotics, Polymeric Carriers, Formulation, Microencapsulation, Enhanced delivery

1-Introduction to Probiotics: Definition, Advantages, and Applications

The word 'probiotic' is Greek and means "for life". The definition has advanced during 4 time[1], and today the most used term is "live organisms that, when administrated in adequate 5 amounts, confer a health benefit on the host"[2]. These health advantages may include 6 inhibiting growth of pathogenic or harmful bacteria, maintaining a healthy gut microbiota, 7 reducing cholesterol level, production of vitamins and antimicrobial agents, stimulation of the 8 immune system, removal of constipation, and improvement of calcium absorption [3-9]. To 9 achieve most of these health effects, the probiotics must survive the low $\mathrm{pH}$ in the stomach and 10 reach the intestine (specially large intestine or colon), where they have to be present in adequate numbers to imply the given health effects[10]. 'Adequate numbers' are expressed as the minimum number of the probiotic bacterial cells in terms of Colony Forming Units per gram $(\mathrm{CFU} / \mathrm{g})$. The issue of how many live bacteria (CFU) are needed to obtain an effect is debated, 14 but currently most probiotics on the market contains typically between 10E7 and 10E9 CFU per oral dose [11]. Lactobacillus and Bifidobacterium are two widely used and studied lactic acid bacterial genera, which are often represented in probiotic products [8, 12-14]. Bifidobacterium breve, Bifidobacterium longum, Lactobacillus fermentum, Lactobacillus plantarum, and Lactobacillus rhamnosus are examples of species of these two genera that play a role in maintaining human health[13, 15]. Lactobacillus spp. and Bifidobacterium spp. 20 convert lactose and/or other carbohydrate sources to lactic acid[16], which is used by other intestinal bacteria to make a variety of short-chain fatty acids, thereby creating an acidic intestinal environment, which is unfavorable for many pathogenic bacteria. Probiotics are currently applied as food supplements with possible effects against gastrointestinal (GI) and non-gastrointestinal diseases such as pathogenic bacterial or viral infections, constipation, 
acute diarrhea, irritable bowel syndrome (IBS), inflammatory bowel disease (IBD), atopic 1 dermatitis, peptic ulcer, colon cancer, coronary heart disease, and urinary tract infections [17- 2 24], although clinical evidence of their effect is typically not yet established. Researchers have 3 proved anti-proliferative or pro-apoptotic features of the probiotics in most common GI cancers 4 such as colonic cancer and gastric cancer [20,24-26]. Other proposed applications of probiotics 5 include weight control and blood sugar normalization[27]. It is important to maintain the 6 viability of probiotics through the conditions encountered during the manufacturing procedure $\quad 7$ (temperature, oxygen, shear, and etc.), storage (moisture, oxygen, and temperature related to packaging and storage), and passage through the GI tract (acidic $\mathrm{pH}$ of stomach and bile salts 9 in the small intestine)[28]. For example, viability of some probiotics decreases after exposure 10 to heat, oxygen, or humidity [29]. Therefore, the use of protective formulations represents an important strategy to preserve the probiotics from harsh environments, and to make sure formulations for delivery of probiotics, classified as 1) non-conventional formulations (commercial food-based products) and 2) conventional pharmaceutical formulations. Our focus in this review is mainly on the use of polymeric carriers as the protective formulation for encapsulation of probiotics. Therefore, we discuss the category of conventional pharmaceutical formulations.

\section{2- Conventional pharmaceutical formulations}

The easiest route to deliver the probiotics to the intestine is through oral delivery. Hence, many 
[35]. In contrast, microcapsules and beads may preserve high viability for probiotics during 1 manufacturing, storage, and delivery to the target site [36-38].

Encapsulation in general refers to a process that entraps a material into another material and 4 produces particles in different scales from nanometer (nanoencapsulation), to micrometer 5 (microencapsulation) or millimeter. The encapsulated part is known as core material, internal 6 phase, active agent or payload phase. The material which is used to encapsulate the core 7 material is called coating membrane, carrier, shell, external phase, or matrix. Probiotics are 8 usually encapsulated through specific encapsulation procedures, such as freeze-drying, where 9 the so-called cryoprotectants are used to preserve the viability of probiotic cells[39, 40]. 10 Encapsulation systems can form different structures known as: reservoir, matrix, or coated 11 matrix. The reservoir type consists of a core that is surrounded by a shell. In the matrix type, 12 the active agent is distributed into the carrier or on the surface, and in the coated matrix type, 13 the so-called matrix is surrounded by an additional coating layer (Figure 1A)[41, 42]. Some 14 examples of different encapsulating systems are shown in Figure 1. As illustrated, 15 encapsulation procedure can lead to different shapes such as spherical, cylindrical, oval, or 16 irregular shapes depending on both encapsulating material(s) and the applied technique. Spraydrying, freeze-drying, emulsion, and melt extrusion are examples of the techniques producing the matrix type. Multilayer emulsion, co-extrusion, and coacervation encapsulation techniques also form the reservoir structure[43]. 

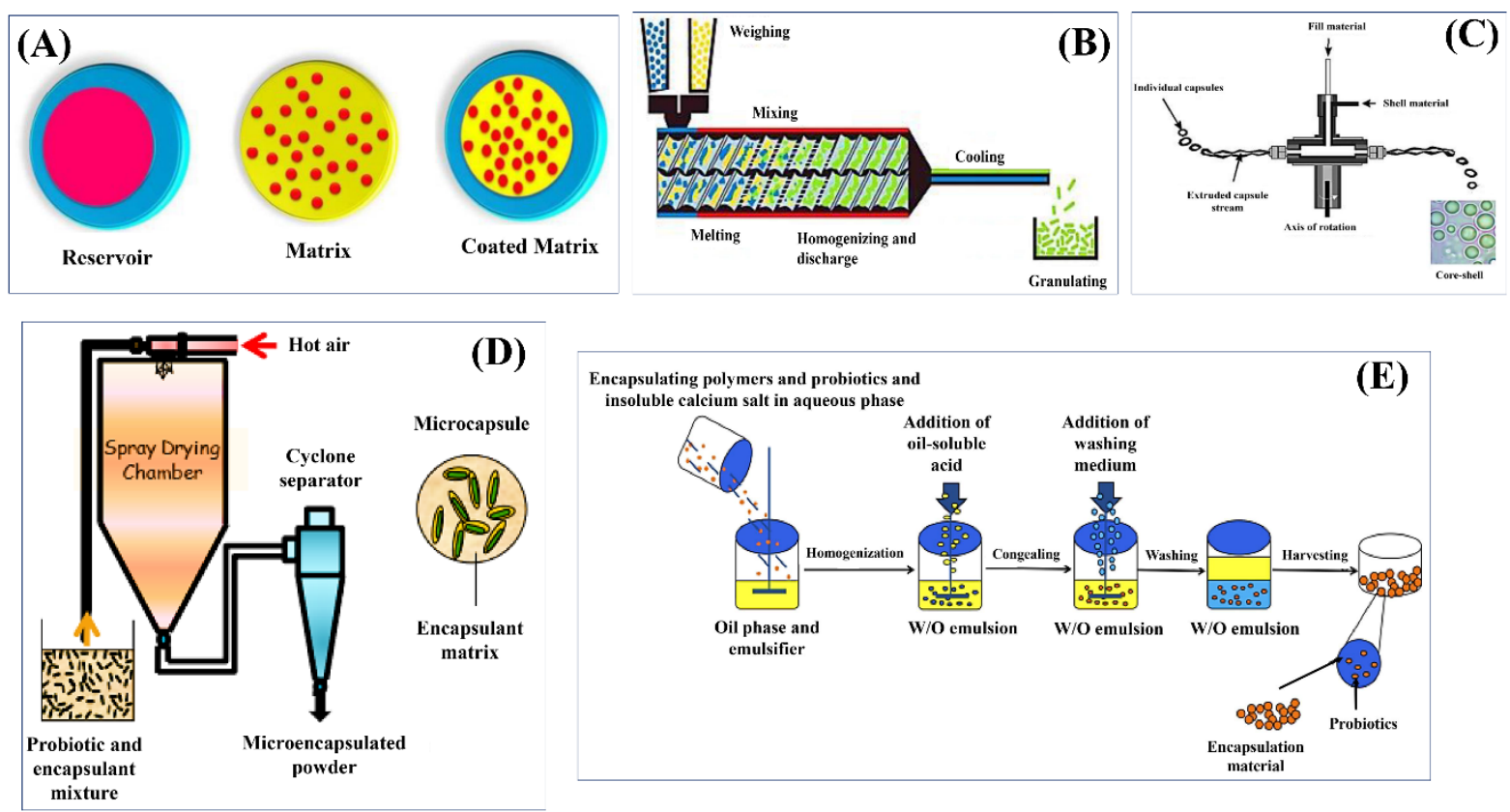

Figure 1. A schematic representation of different encapsulated products (A)[43] and some examples

of the conventional techniques applied for encapsulation including melt extrusion (B) [44], co-

A microcapsule is a capsule in micrometer scale including a solid, liquid or even a gas core that is surrounded by a semipermeable membrane (shell). In probiotic formulations, the 7 membrane acts as a barrier to protect the probiotic cells from the external environment, whilst metabolites and nutrients can transport through the membrane[46, 47]. Microcapsulation has 9 long been applied as an important technique to preserve the viability of probiotics during 10 processing, storage, and acidic conditions of the stomach[48]. Besides, encapsulation facilitates the handling of probiotics as well as controlled dosage of them [49]. For food-based 12 applications, microencapsulated probiotics are usually added into different dairy and non-dairy products like yoghurt, cheese, ice-cream, nutrient bars, biscuits, vegetable and frozen juice[50, 51]. Typically, the carrier materials used for encapsulation of probiotics are biopolymers (proteins or carbohydrates) which can minimize molecular mobility during storage time and thus reduce the degradation rate. Skim milk powder (SMP), soy protein isolates, gum arabic, 
pectin, starch, maltodextrin and sugars are examples of conventional carrier materials used

in food-based compounds[52]. Examples of some commercial encapsulated probiotic cells are

Forever Active Probiotic, Multi-probiotic, Probiotic 7, Cernivet LBC ME10, Pure Baby 3

Probiotic, Geneflora ${ }^{\mathrm{TM}}$, and ThreeLac ${ }^{\mathrm{TM}}$.

With more attention towards use of probiotics in both food-based and non-food compounds, 6 various types of polymers have been applied for encapsulation of probiotics. Polymers which 7 can be used for encapsulation of probiotics must be biocompatible, biodegradable, processable, 8 and neutral to probiotics [53].Biodegradable polymers are a group of polymers that are 9 expected to degrade through a natural process into simpler compounds which can be excreted from the body. Such polymers can be classified in two main groups as naturally-derived or synthetic. Table 1 shows a list of conventional biodegradable polymers used for colon delivery[54].

Table 1. Conventional biodegradable polymers used for colon delivery[54]

\begin{tabular}{|c|c|}
\hline Yatural polymers & Synthetic polymers \\
\hline 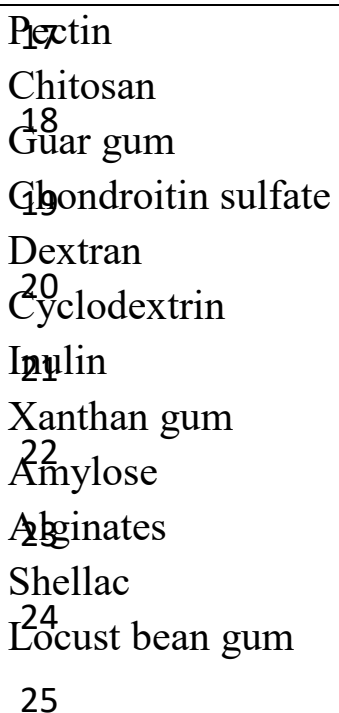 & $\begin{array}{l}\text { Eudragit L } 100 \\
\text { Eudragit S } 100 \\
\text { Eudragit L } 30 \text { D } \\
\text { Eudragit RS } 30 \text { D } \\
\text { Eudragit L 100-55 } \\
\text { Polyvinyl acetate phthalate } \\
\text { Hydroxypropyl ethylcellulose phthalate } 50 \\
\text { Hydroxypropyl ethylcellulose phthalate } 55 \\
\text { Cellulose acetate trimellitate } \\
\text { Cellulose acetate phthalate }\end{array}$ \\
\hline
\end{tabular}


There are several functional classifications for polymers which are used as carrier for 1 encapsulation of probiotics including enzyme-sensitive polymers, $\mathrm{pH}$-sensitive polymers, and 2 redox-sensitive polymers. Some details are given in following sections.

\section{4-1- Enzyme-sensitive polymers}

Enzyme-sensitive polymers are one of the main groups of polymers used for target delivery of 5 probiotics. There are many polysaccharides which are placed in the category of enzyme6

sensitive polymers. Various hydrolytic enzymes such as $\beta$-D-galactosidase, $\beta$-D- glucosidase, 7 glycosidase, amylase, pectinase, dextranase, and $\alpha$-D-xylosidase are secreted in the colon. Such enzymes cleave glycoside bonds of the polysaccharides. Therefore, these bonds remain stable 9 in the stomach and small intestine, but degrade in the colon[55]. Amylose, chitosan, 10 chondroitin sulfate, cyclodextrin, dextran, inulin, guar gum, pectin, and locust bean gum are in the class of enzyme-sensitive polysaccharides that can be used as carriers for targeted delivery of pharmaceuticals or probiotics to colon $[54,56,57]$.Chitosan is the most popular cationic linear polysaccharide with a random distribution of $\beta$-D-glucosamine and N-Acetyl-Dglucosamine. Chitosan is biocompatible, biodegradable, and non-toxic, making it appropriate for food and pharmaceutical applications[58, 59]. Chitosan has the ability to interact with anionic polymers[60] and also with negatively charged mucosal surfaces. The latter is very important for oral delivery $[61,62]$.

\section{4-2-Redox-sensitive polymers}

Colonic microflora produces reducing enzymes such as nitroreductase, azoreductase, $\mathrm{N}$-oxide 
colon. The most common form of reducing enzymes is azo-reductase enzyme which reduces

azo-linkages in the azo-containing polymers (such as azo-containing polyurethanes and 2

azopolymeric hydrogels) and leads to release the probiotics [64-66]. As the first research on 3 designing azo-linkage carriers, Saffran et al coated entrapped protein drugs with copolymers of styrene and 2-hydroxyethyl methacrylate (HEMA) cross-linked with divinyl azobenzene (DVAB) and used for colon delivery[67, 68].

\section{4-3-pH-sensitive polymers}

$\mathrm{pH}$ differences between the stomach, small intestine, and colon in the gastrointestinal tract calls for use of $\mathrm{pH}$-sensitive polymers for targeted delivery of probiotics to the site of interest. These 9 polymers can preserve the probiotics in acidic $\mathrm{pH}$ of the stomach and deliver them in higher 10 $\mathrm{pH}$ in the colon and ileum. Examples of synthetic $\mathrm{pH}$-sensitive polymers are acrylic acid derivatives, cellulose polymers such as cellulose acetate phthalate (CAP), cellulose acetate trimellitate, hydroxypropyl methylcellulose acetate succinate (HPMCAS), and hydroxypropyl

methyl-cellulose phthalate (HPMCP) 50 and 55. Also, Eudragit ${ }^{\circledR}$ polymers are in the class of 14 synthetic $\mathrm{pH}$-responsive polymers produced by polymerization of acrylic and methacrylic acids or their esters like butyl ester or dimethylaminoethyl ester. Anionic Eudragit L is applied for enteric applications because of its dissolution at $\mathrm{pH}>6$ while Eudragit $\mathrm{S}$ dissolves at $\mathrm{pH}>7$ for colon targeting[69]. Shellac, a product of natural resin lac, is another synthetic $\mathrm{pH}$-sensitive polymer which is appropriate for colon targeting[54]. Alginate, as a natural anionic polysaccharide, is a combination of $\beta$-D-mannuronic and $\alpha$-L-guluronic acids blocks $[59,70]$ which is non-toxic, biocompatible, and cost-effective [71]. The guluronic acid blocks in this polymer can form a physical hydrogel with divalent cations such as $\mathrm{Ca}^{2+}$ or $\mathrm{Ba}^{2+}$. The binding 
more porosity and mechanical stability of the hydrogels [72]. Alginate is applied in a salt form, 1

which is commonly sodium alginate[73]. Hydrogel formation between sodium alginate and 2

calcium ions leads to formation of alginate microparticles. These microparticles impart a $\mathrm{pH}-$ sensitive swelling and release[59, 65, 70,74]. For example, in a study performed by Tiwari et 4 al sodium alginate-based beads prepared along with guar gum succinate or guar gum showed 5 both $\mathrm{pH}$-sensitive and enzyme-sensitive release in colon due to presence of sodium alginate 6 and guar gum respectively (Figure 2A)[55]. Another example of a pH/enzyme-sensitive 7 delivery system is displayed in Figure 2B., where a chitosan/nanocellulose/sodium alginate 8 polysaccharide carrier is used for dual delivery of two drugs (5-Fluorouracil and levamisole 9 hydrochloride) into the colon[75]. It is worth noting that delivery systems based-on $\mathrm{pH}-10$ responsive carriers have some limitations. For instance, the $\mathrm{pH}$ values in the gastrointestinal tract can be affected by some internal and external factors such as diet or diseases. Hence, a

(A)

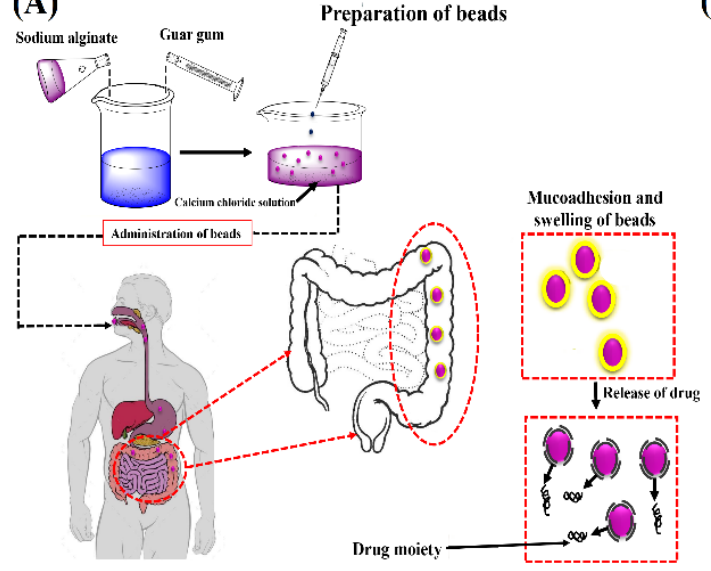

(B)

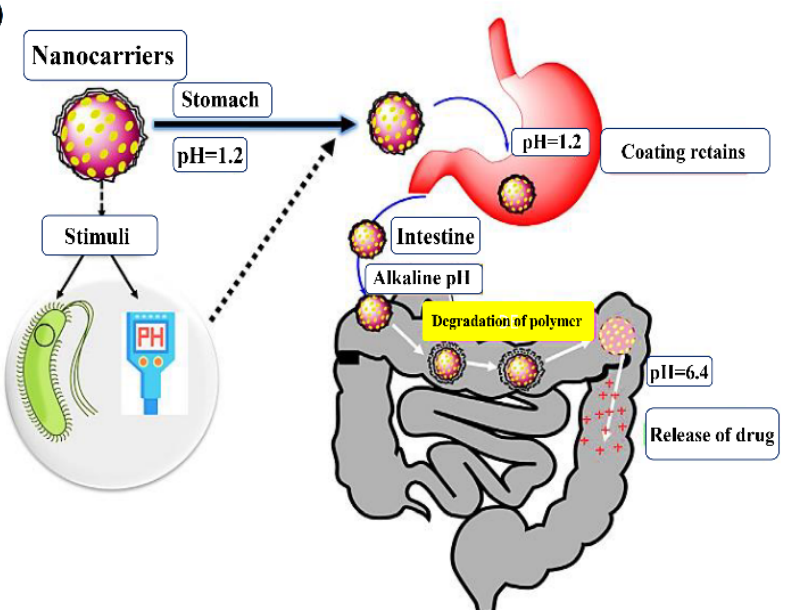


Figure 2. Examples of pH/enzyme sensitive delivery systems using sodium alginate-based

\section{4-4-Other polymeric carriers}

Proteins are another important group of polymers that are used for encapsulation of probiotics 5 thanks to their amphiphilic nature[77]. The most common proteins used for encapsulation of 6 probiotics include gelatin[78], whey protein[79], and casein[80]. From synthetic polymers, 7 Polyesters (such as poly (D, L-lactic-co-glycolic acid) (PLGA)), polyacrylamides, and 8 polyvinyl alcohol (PVA) are some other examples applied for delivery of probiotics[77]. Use 9 of synthetic polymers such as PLGA is however limited for encapsulation of probiotics due to 10 involvement of organic solvents for solubilizing the polymers during fabrication, which can cause cell damage.

Amongst several microencapsulation techniques, selection of the right method depends on the required particle average size, physical and chemical properties of the carrier, application of the encapsulated material, the release mechanism, and cost of the procedure [81, 82]. Moreover, these techniques must be gentle towards the probiotic cells. Some of the common encapsulation techniques are shown in Figure 3. 


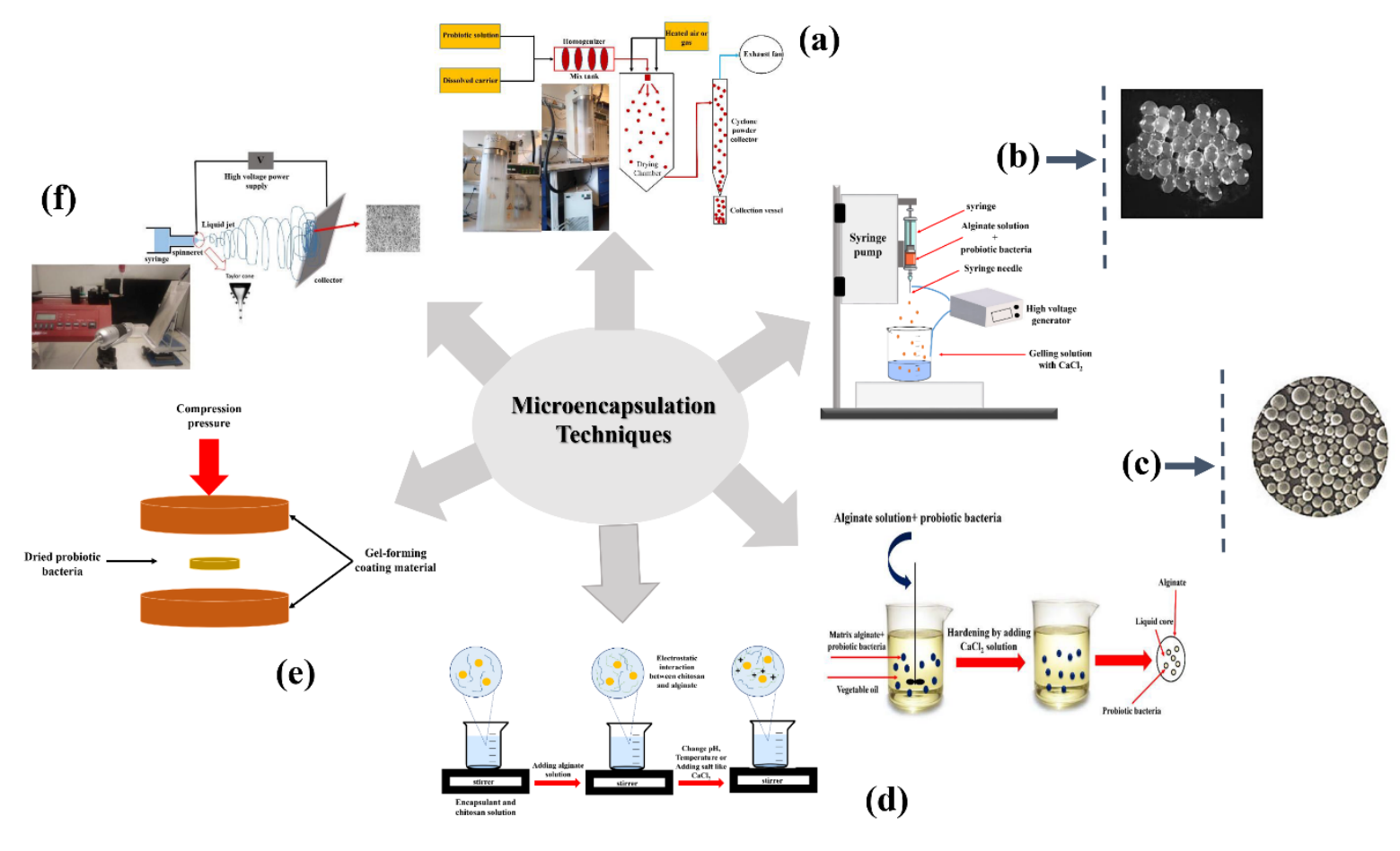

Figure 3. Common techniques for microencapsulation of probiotics including: (a) Spray-drying 2

[83], (b) Extrusion [84] to produce beads[85], (c) Emulsion technique[82] to produce capsules [85], 3

(d) Complex coacervation to form chitosan-alginate nanoparticles[86], (e) Compression coating[83], 4 and (f) Electrospinning.

The very first applied microencapsulation techniques were spray-drying, freeze-drying, foam 6 drying, and fluidized bed drying. These techniques are used to preserve the probiotics and 7 increase their shelf-life by a desolvation process. In spray-drying(SD) (Figure 3(a)) [87, 88], 8 an aqueous or oily solution of the probiotics and dissolved carrier go through an atomizer or 9 spray nozzle to form a mist and disperse the slurry into a controlled drop size spray. Then the 10 drops enter into a drying chamber, where a hot gas flow (air or nitrogen) is blown into the 11 chamber whereby the solvent evaporates. Finally, the capsuled particles are transported into a cyclone separator for recovery[82, 89]. The spray drying (SD) method is used in large-scale industrial applications. One of the limitations in this technique is the reduction of the viability of probiotics and their activities because of the high temperatures that are usually used for solvent evaporation[49]. This is particularly a problem for bacteria belonging to the so-called 
Gram-negative group, which have a more complex and fragile cell membrane[90]. Another 1 procedure known as freeze drying (FD) or lyophilization[91] has been reported to overcome 2 the disadvantages in related to spray drying[92]. In FD, the probiotics are frozen along with 3 the carrier material at temperatures between -20 to $-30{ }^{\circ} \mathrm{C}$ and the water is removed under 4 vacuum by sublimation (primary drying) and then by desorption (secondary drying[93]). After 5 lyophilization, cryoprotectants are added to maintain and stabilize the probiotic activity during 6 the storage. The most commonly used cryoprotectants are lactose, trehalose, sucrose, sorbitol, 7 milk protein, and skim milk[94]. Compared to spray drying, lyophilized probiotics have higher 8 storage stability, especially at low temperatures and inert atmosphere of nitrogen or 9 vacuum[95]. The price of lyophilization is 4 to 7 times higher than spray drying. In usual 10 vacuum freeze driers, energy consumption is very high that is because of poor heat transfer rate and long drying time [96]. The duration of lyophilization changes with the square of the sample thickness. Further, lack of particle size control during FD of aqueous solution is the major drawback in this technique[97]. An alternative to FD is spray freeze drying (SFD) [94, 98]. This procedure combines common steps applied in SD and FD. The advantages of SFD are better control of size and higher specific surface area in comparison with SD encapsulated 16 particles. However, there are drawbacks also in this method including high energy consumption, long processing time, and high cost compared to $\mathrm{SD}[82]$. Another method is spray-cooling that is similar to SD, but the carrier material and work conditions are different. In this technique, a molten carrier that has low melting point is utilized to encapsulate the probiotics. The carrier material is solidified, when the mixture of carrier and the probiotics enter into a cold air flow [99]. In addition, vacuum-drying is another microencapsulation 22 method similar to FD, but the material is not frozen in this technique and the procedure is done at $0-40{ }^{\circ} \mathrm{C}$. These alternative drying techniques have shown good cell stabilization during time. However, the absence of water or solvent does not always give sufficient protection against 
stressing conditions such as acidic $\mathrm{pH}$, high temperature, high humidity, or presence of light. 1 To resolve these limitations, combined treatments are used to enhance the protective 2 effect[100]. For instance, encapsulation methods are further used to increase the protection of 3 the previously dried probiotic forms (dried by spray drying, freeze-drying, etc.). Extrusion and 4 emulsion are two techniques that have been developed to further improve the protection of the 5 probiotics. Extrusion and emulsion are intended to make gel beads and capsules, 6 respectively[101]. In both techniques, hydrocolloids (aqueous dispersion of a carrier such as 7 natural or synthetic polymer) and probiotics (in the form of lyophilized powder or slurry) are 8 used. In the extrusion technique (Figure 3(b)), the hydrocolloid (often alginate or carrageenan) 9 is combined with probiotics and is injected into an extruder (pilot scale) or a syringe needle 10 (laboratory scale). Then, contents of the mixture are dripped by using a needle or a nozzle into a gelling or hardening solution such as calcium chloride. This technique allows preservation of a high number of probiotic cells because it makes virtually no damage[102]. The main limitation of this method is the difficulty with using it in large-scale production because the microspheres are formed slowly. In the emulsification or emulsion technique (Figure 3(c)), the discontinuous phase (a mixture of hydrocolloid and probiotics) is dispersed into the continuous phase (a large volume of oil). Then, homogenization of this mixture is performed by stirring and adding an emulsifier to produce water-in-oil (w/o) emulsion. When the w/o emulsion is formed, the water-soluble polymer becomes insoluble and produces the particles within the oil phase. Finally, the mixture is centrifuged to make two layers, where the oil phase and aqueous phase are separated to receive the microcapsules $[45,103,104]$. makes gelled droplets called beads. 
2. The product of emulsification (capsule) has a liquid core, but the core of the bead has a 1 porous network[105]. 2

3. The dimensions of the capsules are much lower (at least 100 times) than those of the 3 beads[106].

4. Capsules are unequal in the size and shape but the shape of beads is uniform. 5

Taking this into consideration, the emulsification method has some disadvantages including 6 emulsion instability, vigorous stirring, random incorporation of the probiotics into the capsules, 7 inability of sterilization of oil if necessary, and production of a wide range of particle size and 8 shapes [82, 106, 107], fluid-bed agglomeration and coating is used as an alternative method. 9 This method is based on fluidizing air to create a uniform circulation of particles. An atomizing 10 nozzle is utilized for atomizing a coating material which solidifies by lowering the temperature 11 or evaporating the solvent[83]. This method is the most applicable method among other 12 techniques for coating the probiotics in industrial production because of high throughputs[108]. Coacervation is another encapsulation technique based-on layer precipitation of one polymer 14 (simple coacervation) or several polymers (complex coacervation) by phase separation. The 15 main driving force for the coacervation technique is electrostatic attraction between particles 16 with opposite charges. If this attraction is induced between a charged bioactive component (like 17 charged probiotic) and a polymer with opposite charge, the procedure is called simple coacervation. If a probiotic is trapped via electrostatic interactions of two polymer types being positively charged (e.g. chitosan) and negatively charged (e.g. pectin and alginate), then it is 20 called complex coacervation[86]. Benefits of coacervation compared to other encapsulation 21 methods for probiotics, are low-cost process (does not involve high temperatures or organic 22 solvents) and incorporation of a large amount of probiotics into the carrier. However, the scaleup of coacervation is difficult because it is a batch process that produces coacervate in an 24 aqueous solution. Therefore, an extra drying process, which can be harmful to the probiotic 
cells[83] must be used to enhance its shelf-life. An example of complex coacervation is the formation of coacervates from cationic chitosan and anionic alginate (Figure 3(d)). 2 Compression coating method (Figure 3e) is another technique that compresses dried probiotics powder into a core tablet or pellet and compresses the coating material around the core to 4 produce the final product. This method has attracted attention for probiotics encapsulation as 5 it enhances the stability of lyophilized probiotic bacteria during the storage[109]. High-voltage 6 electrospinning (fiber forming) and electrospraying (particle forming) are also effective 7 methods to prepare sub-micron or nano-scale polymer fibers or particles (Figure 3f) [110-113]. This technique has been reported for both encapsulation of live probiotic bacteria, and for 9 further protection of dried probiotics (for example FD) [114]. Electrospinning has been recognized as a feasible method for encapsulation of bioactive compounds[115] (such as probiotics) because it does not comprise any severe conditions of pressure, or temperature. The main components of the electrospinning method include as electric field, a syringe pump connected to a metallic needle, and a collector. Applying an electric field between the needle tip and the collector, distorts the surface of the formed droplet like a conical shape and stretches it until a critical point, where a stream of liquid erupts from the surface. As a result, fibers are made and get collected on the surface of the collector [116-120]. Some other methods for encapsulation of probiotics include: emulsion-droplet coalescence, emulsification/solvent evaporation method, salting-out, ultra-sonication, high-pressure homogenization, emulsiondiffusion method (EDM), supercritical fluid (SCF), precipitation of pressurized emulsions or hydrogels[86].

\section{6-Factors affecting storage stability of encapsulated probiotics}

Storage is one of the key steps affecting the stability of the probiotics. In this section, we review the main factors affecting the viability of encapsulated probiotics during storage. Various parameters such as storage temperature, type of encapsulating material (carriers as well as 
additives such as prebiotics and lyoprotectants), encapsulation technique, relative humidity, 1 and oxygen content affect the viability of encapsulated probiotics during storage (Figure 4)

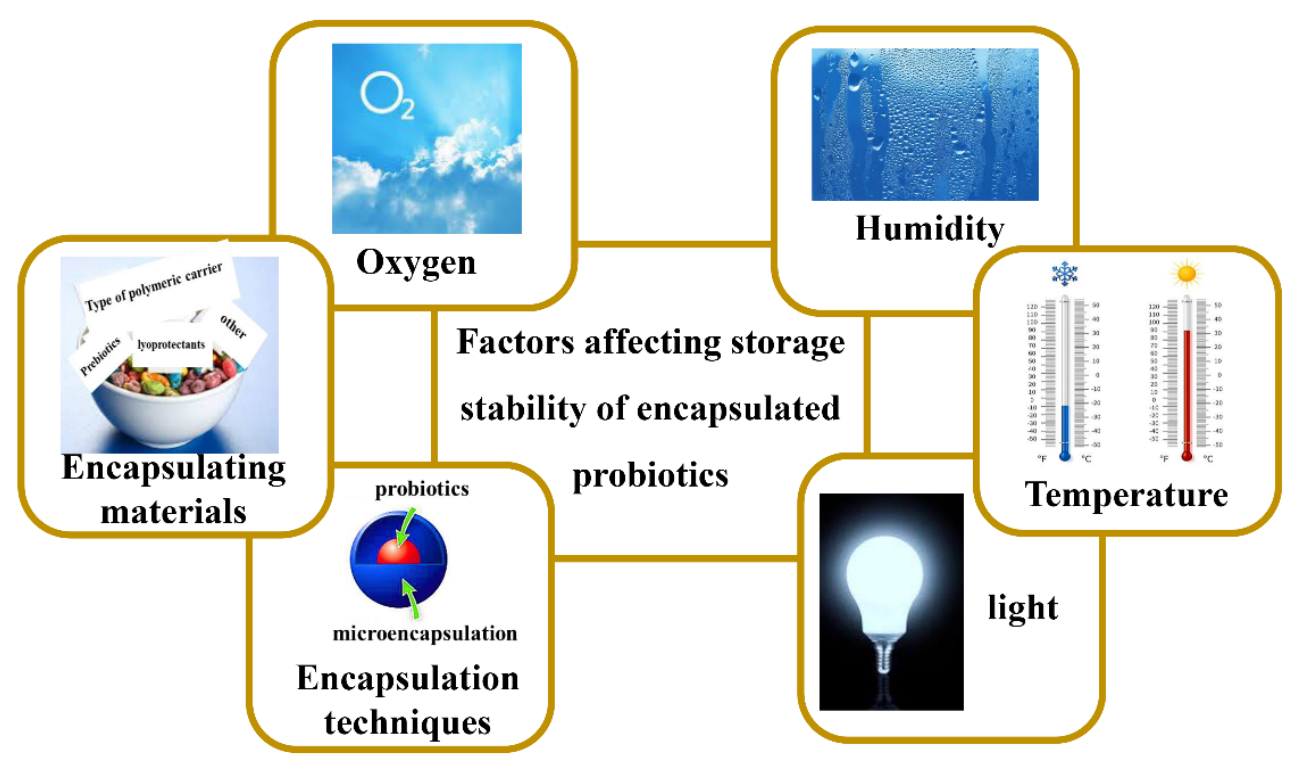

Figure 4. The main factors affecting the viability of encapsulated probiotics during storage 4 including temperature, humidity, encapsulating materials, and encapsulation techniques. 5

Temperature is a key factor affecting bacterial survival during storage. To study the effect of 6 temperature on storage, Poulin et.al. compared the viability of Bifidobacterium longum HA- 7 135 encapsulated in tablets of succinylated $\beta$-lactoglubin. They reported high stability at $4{ }^{\circ} \mathrm{C} \quad 8$ for 3 months ( $0.6 \log$ reduction during 12 weeks) whilst the survival of bacteria decreased with 9 increasing the storage temperature to $25{ }^{\circ} \mathrm{C}$ (5.2 log reduction during 12 weeks). This 10 temperature effect can be attributed to oxidation reaction (positive redox potential) in the presence of oxygen especially for anaerobic bacteria such as Bifidobacterium. In other words, enhancing the temperature from $4{ }^{\circ} \mathrm{C}$ to $25^{\circ} \mathrm{C}$, increases the rate of oxidation and consequently decreases the viability of such anaerobic cells. Therefore, oxygen impermeable packages or oxygen-free storage atmospheres are recommended for higher viability and storage stability of many probiotic strains[34]. In another study, Lancuški et. al fabricated Starch-formate/glycerol (SFG) fibers with encapsulated Lactobacillus paracasei. The encapsulated fibers were stored 
at $4{ }^{\circ} \mathrm{C}, 25^{\circ} \mathrm{C}$, and $37^{\circ} \mathrm{C}$ for comparing their storage stability during 3 weeks. Authors observed 1 that viability of the encapsulated bacteria remained stable at $4{ }^{\circ} \mathrm{C}$ and $25{ }^{\circ} \mathrm{C}$, but decreased at 2 $37^{\circ} \mathrm{C}[119]$.

The effect of both temperature and humidity on storage of probiotics was studied by López4 Rubio et al, where they encapsulated Bifidobacterium animalis subsp. Lactis Bb12 strains 5 using whey protein concentrate (WPC) or pullulan. In brief, first they prepared probiotic cell 6 suspensions in PBS or in skimmed milk, then they prepared WPC or pullulan solutions either 7 in PBS or skimmed milk. Finally, the capsules were fabricated using electrospraying or freeze8 drying. The storage stabilities were conducted at two temperatures $\left(20{ }^{\circ} \mathrm{C}\right.$ and $\left.4{ }^{\circ} \mathrm{C}\right)$ and at 9 different relative humidities (RH). Their results showed that PBS was not an optimum media 10 for making the bifidobacterial strain solutions compared to skimmed milk. Regarding the effect of temperature, higher viabilities were achieved at $4{ }^{\circ} \mathrm{C}$ compared to $20{ }^{\circ} \mathrm{C}$ for both WPC and Pullulan. However, at $20{ }^{\circ} \mathrm{C}$, electrosprayed WPC maintained higher viabilities compared to freeze-dried WPC. Authors further studied the effect of RH on storage viability using WPC14 based capsules only. They observed higher viabilities for electrosprayed capsules of WPC than 15 freeze-dried WPC capsules at all humidities of $0 \%, 11 \%, 53 \%$, and $75 \%$. RH of $11 \%$ was 16 shown to be the best humidity condition for room temperature storage of $\mathrm{Bb} 12$. [49].

To compare if coating the freeze-dried probiotics would improve their storage stability, Librán et al coated freeze-dried Bifidobacterium longum subsp. Infantis capsules by different 19

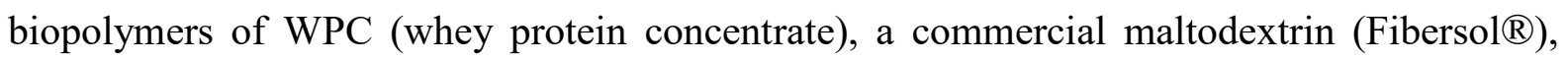
20 polysaccharide maltodextrin, Zein and PVP using electrospraying technique. The storage conditions were temperatures of $23{ }^{\circ} \mathrm{C}$ or $37^{\circ} \mathrm{C}$, and $\mathrm{RH}$ of $0 \%$ or $23 \%$ and lasted for up to 600 days. In general, coated freeze-dried bacteria showed improved viability especially at longer 23 storage times of more than 250 days. Also, all encapsulated Bifidobacteria showed decreased 
viability at $37{ }^{\circ} \mathrm{C}$ and $23 \% \mathrm{RH}$. By lowering the storage temperature from $37{ }^{\circ} \mathrm{C}$ to $23{ }^{\circ} \mathrm{C}$ at $\quad 1$ $23 \% \mathrm{RH}$, the cell viability improved. WPC, Fibersol, and PVP showed the best survival of the 2 bacteria at $23 \% \mathrm{RH}$ and $23{ }^{\circ} \mathrm{C}$ thanks to their effective protective barrier against humidity 3 and/or oxygen[114]. To further assess the role of encapsulating materials on maintaining 4 storage stability, Rajem et al. prepared microcapsules containing Lactobacillus plantarum 5 (MTCC 5422) using spray freeze drying (SFD) or freeze drying (FD) techniques. They used 6 four encapsulation materials: 1) whey protein isolate (WPI) with sodium alginate (SA), 2) WPI 7 with fructooligosaccharide prebiotic (FOS), 3) denatured WPI (DWPI) with SA, and 4) DWPI 8 with FOS., and evaluated the impact of storage temperature, amount of moisture, encapsulation 9 technique (SFD against FD) and encapsulating materials on the cell viability during 60 days 10 storage. They observed that higher content of remaining moisture after drying leads to more 11 loss in the cell viability during the storage. DWPI with FOS microcapsules displayed the 12 highest storage stability, which seems to be due to the presence of FOS prebiotic (it has been confirmed that incorporation of prebiotics improves the viability of probiotics[121]) and the role of DWPI in insulating against entering of water vapor. Also, the microcapsules produced by SFD showed higher viability of the probiotic during storage against microcapsules produced by FD [122]. Wai-Yee Fung et. al. also produced L. acidophilus encapsulated electrospun nanofibers from soluble dietary fiber of okara (soybean solid waste), oil palm trunk (OPT), and oil palm frond (OPF). The viability of the L. acidophilus probiotic was shown to be affected by high moisture content and the oxygen level. They also confirmed that the probiotic bacteria were stable toward high voltage and shear stress of electrospinning. Authors observed a survival of $72 \%$ for OPF, whilst OPT and okara nanofibers showed $49 \%$ and $37.7 \%$ respectively during a 21 days storage time[117]. Katja et. al. also reported storage stability of Lactobacillus plantarum ATCC 8014 encapsulated poly (ethylene oxide) (PEO) electrospun nanofibers in the lack and presence of lyoprotectant at storage temperatures of $4{ }^{\circ} \mathrm{C}$ and $25{ }^{\circ} \mathrm{C}$ 
during 24 weeks. The viability of the L. plantarum cells encapsulated PEO nanofibers 1 completely decreased at $25{ }^{\circ} \mathrm{C}$ after 24 weeks while in the L. plantarum cells encapsulated 2 $\mathrm{PEO} /$ sucrose nanofibers, the viability improved and the highest viability of the probiotic was 3 reported for L. plantarum cells encapsulated PEO/trehalose nanofibers (at $25^{\circ} \mathrm{C}$ for 24 weeks). $\quad 4$ L. plantarum cells encapsulated into PEO nanofibers showed higher viability at $4{ }^{\circ} \mathrm{C}$ compared 5 to $25^{\circ} \mathrm{C}$ during the 24 weeks evaluation procedure. However, the viability of $L$. plantarum cells 6 in the $\mathrm{PEO} /$ trehalose and $\mathrm{PEO} /$ sucrose nanofibers decreased only $0.2 \log$ units and $0.5 \log 7$ units, respectively (after 24 weeks at $25^{\circ} \mathrm{C}$ ), showing the role of adding lyoprotectant into 8 carrier formulation for maintaining the storage stability of the PEO nanofibers at room 9 temperature. They also studied the effect of some other parameters such as applied voltage and relative humidity during the electrospinning, as well as concentration of applied probiotic and lyoprotectant on the viability of the probiotic. Although, optimum voltage of $15 \mathrm{kV}$ and $\mathrm{RH}$ of $55 \%$ were selected to gain the best viability, they concluded that these parameters do not have critical impact on the cell viability. All in all, authors found that the concentration of L. plantarum cells and the lyoprotectant in the PEO solution are the two most important factors which not only affect the probiotic viability after electrospinning but also have an important role in maintaining the viability during storage[123].

So far, we have discussed different systems for encapsulation of probiotics and the factors hydrogels such as alginate are widely used for encapsulation of probiotics. However, such formulations suffer from uncontrollable swelling, fragility and chemical lability, all leading to leakage of the entrapped probiotic[124]. To overcome these limitations, extra treatments such as coating the matrices are usually performed. For instance, coating alginate matrices with 
interaction between positively charged amino groups of chitosan with negatively charged carboxylic acid groups of alginate forms a more protective shell [126]. Layer-by-layer coating 2 of alginate matrices with chitosan-alginate has also shown to further improve the protective 3 effect [127-129]. For instance, Cook et al encapsulated Bifidobacterium breve into an alginate 4 matrix and used chitosan for layer-by-layer coating of alginate. During the exposure to in 5 vitro gastric conditions, they observed increased viability in a 3-layer coated matrix $(8.84 \pm 0.17 \log \quad 6$ CFU per mL), compared with free cells (viability of $<3 \log$ CFU per $\mathrm{mL}$ ) [128]. Addition of 7 cationic polylysine to alginate has also indicated an effective protection against harsh 8 environments and improved viability of the encapsulated probiotics[130]. Cui et al used an air 9 atomization method to prepare the alginate poly-l-lysine small microparticles containing 10 bifidobacteria. The survival of bifidobacteria increased a lot under low $\mathrm{pH}$ conditions. Also, 11 their survival was maintained at over $10^{7} \mathrm{cfu} / \mathrm{g}$ during 16 weeks storage at $4^{\circ} \mathrm{C}[130]$. This group performed another study to compare delivery of bifidobacteria using 1) protected bifidobacterial-loaded alginate poly-l-lysine microparticles or 2) unprotected bifidobacterial cultures via oral administration to healthy human volunteers within 1-month study. They collected fecal samples from healthy human volunteers at different time points before and after dosing the bacteria, and compared the viability of the total lactic acid bacteria, bifidobacteria, 17 staphylococci, and enterobacteriaceae in the feces. In brief, they weighed an aliquot of the fecal samples, suspended in neutral phosphate buffer solution supplemented with L-cysteine $\mathrm{HCl}$ $(0.05 \%)$, diluted in decimal steps (down to $\left.1: 10^{8}\right)$, and plated the dilutions. They observed 20 significantly higher viability of bifidobacteria in the feces of the group taking protected microparticles than the group taking the free bifidobacterial culture. However, there was no 
(SGF) for 2 hours, and observed a 1000-fold decrease in viability of the bacteria in protected

micro-particles. The decrease in unprotected bifidobacteria was much higher $\left(10^{8}\right.$ fold $)[131]$.

Alginate-polylysine-alginate (APA) microcapsule is another promising system. Martoni et al investigated APA microcapsules for delivery of Live Lactobacillus plantarum 80 strains. These APA microcapsules preserved cell viability over $10^{9}$ and $10^{6} \mathrm{CFU} / \mathrm{mL}$ at $\mathrm{pH} 2.5$ and $\mathrm{pH} 2.0$ respectively after 2-hour residence times in the simulated stomach. Residence times in the 6 simulated intestine (up to 12 hours) also led to viability of over $10^{10} \mathrm{CFU} / \mathrm{mL}$ [132]. Urbanska 7 et al used APA microcapsules loaded with L. acidophilus blended with Liberty plain yogurt in 8 multiple intestinal neoplasia (Min) mice as a model of colorectal cancer. They observed 9 beneficial actions of microencapsulated bacteria in yogurt and potential for its use for treating colon cancer, as it resulted in minimizing intestinal inflammation, and delaying overall polyp progression in the mice[133]. APA microcapsules have been highly utilized for live cell therapy. However, they do not have adequate stability in the GI tract, which is a limitation for oral administration $[134,135]$. To resolve this problem, APPPA (alginate-polylysine-pectinatepolylysine-alginate) multilayers were prepared for oral delivery of probiotics[136]. The APPPA multilayer microcapsules indicated better stability in GI tract and higher permeability for cell encapsulation in comparison with the APA microcapsules[136]. Alginate-chitosanalginate (ACA) microcapsule is an alternative candidate. ACA microcapsules have indicated higher stability and better protection of the entrapped probiotics than APA microcapsules[137]. Alginate and chitosan have been further modified to enhance the viability of probiotics under 20 acidic conditions. Le-Tien et al fabricated succinylated alginate, succinylated chitosan and Npalmitoylaminoethyl alginate for encapsulation of L. rhamnosus and showed 60, 66, and 87\% 22 viability in simulated gastric fluid $(\mathrm{pH} 1.5)$ respectively. The highest viability and protection were seen for the L. rhamnosus loaded in N-palmitoylaminoethyl alginate [138]. They did not use palmitoylated chitosan, since palmitoylated chitosan is insoluble in aqueous solutions and 
cannot make bead-forming solutions[139]. Coating of alginate beads by whey protein has also 1 been investigated as another probiotic carrier [140,141]. Gbassi et al showed that whey protein 2 coating significantly improved the survival of Lactobacillus plantarum spp. in alginate 3 beads[141]. Kailasapathy K. used combination of alginate and modified starch to encapsulate 4 L. acidophilus and B. lactis. They observed enhanced viability of 100 fold and 10 fold of $L . \quad 5$ acidophilus and B. lactis respectively[142]. Polydopamine has been also used as a coating 6 material. Polydopamine coating of alginate beads including probiotics increased the 7 mechanical stability of alginate beads, prevented the entrapped probiotics (Saccharomyces 8 cerevisiae) from leaking (for more than $25 \mathrm{~h}$ ), and prevented bead swelling [124]. Protamine 9 is another candidate for coating/encapsulating of probiotics. Protamine degrades by proteases in small intestine (SI), and therefore leads to rapid target release in the SI. In a study carried out by Mei et al, a core-shell carrier composed of a Ca-alginate/protamine (CAP) composite as shell and a L.-casei-encapsulated Ca-alginate (CA) as core was produced by a co-extrusion minifluidic and subsequent adsorption method. The product showed improved protection of L.-

(a)

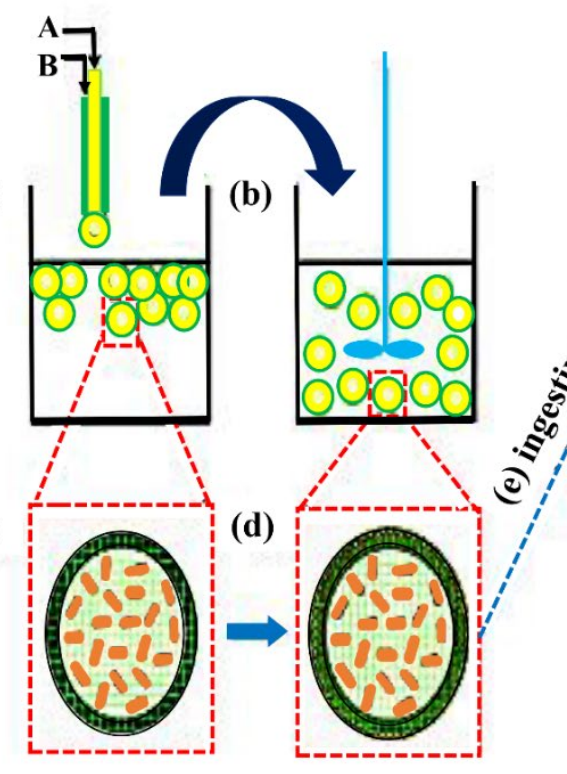


Figure 5. A schematic representation of fabrication and use of protamine coated L.-casei-

beads are produced by the coextrusion method $(\mathrm{a}, \mathrm{c})$, where Na-alginate solution containing

Lactobacillus casei (A) is covered by pure Na-alginate solution (B), Then CAP beads are produced by

Coating of alginate capsules by surfactants is also a novel technique to increase the viability of encapsulated probiotics. Surfactants are defined as surface-active materials and are classified 9 to anionic, cationic, non-ionic, and zwitterionic materials[144]. Donthidi et al used lecithin 10 (zwitterionic surfactant) for encapsulation of Lactobacillus casei into alginate and starch. The results proved that the storage stability of this probiotic (at 4,23 , and $37^{\circ} \mathrm{C}$ ) increased in the presence of lecithin surfactant. The survival of the probiotic was reported above 6 Log CFU $\mathrm{mL}^{-1}$ at $23{ }^{\circ} \mathrm{C}$ for 12 weeks and $6 \mathrm{Log} \mathrm{CFU} \mathrm{mL}-1$ at $37{ }^{\circ} \mathrm{C}$ for 2 weeks. Also, Chen et al confirmed the improved survival of Lactobacillus and Bifidobacterium bacteria in the alginatechitosan capsules coated with lecithin vesicles exposed to both simulated gastric and intestinal fluids[145]. In a recent study, Albadran et al coated alginate capsules containing Lactobacillus plantarum bacteria with different surfactants including sodium dodecyl sulfate (SDS, anionic), ammonium lauryl sulphate (ALS, anionic), dimethyldioctadecylammonium (DDAC, cationic), benzalkonium chloride (BZK, cationic), hexadecyltrimethylammonium bromide (CTAB, 20 cationic), and zwitterionic lecithin. It was shown that coating the capsules by CTAB, BZK, 21 ALS, and SDS decreased the viability of the probiotic for 4-9 $\log$ CFU/g when exposed to the 22 simulated gastric (SGF; 1 hour) and intestinal (SIF; 2 hour) fluids, whilst there was much lower decrease ( $\sim 3 \log$ CFU/g) with uncoated capsules. However, coating the alginate capsules with DDAC led to almost complete recovery of viable cells $(\sim 0.3 \log$ CFU/g decrease $)$ under same conditions of exposure to SGF and SIF. In fact, the physicochemical interactions between the 
surfactants and alginate capsule (for example, interaction between hydrophilic sulfonate groups

in SDS and ALS and the hydroxyl groups of alginate) maintains viability of the encapsulated

probiotic [146].

Enteric-coating materials such as Eudragit have also been used for target delivery of probiotics.

A comparison between Eudragit L 10055 alone with blend of ethyl cellulose and Eudragit 6

L100 55 for coating of $B$. breve showed the advantage of the blend for protection of the bacteria

7

in acidic condition [147]. de Barros et al also used Eudragit for acidic protection and target

8

delivery of L. casei [148]. They used combination of micro-crystalline cellulose (MCC), 9

sodium alginate, lactose and $\mathrm{CaCl}_{2}$ in their formula. $\mathrm{MCC}$ was selected as the excipient for 10

extrusion-spheronization due to its ideal rheological properties, excellent binding and

cohesiveness[149]. Live L. casei were added directly in the combination liquid, and the

combination went through granulation, extrusion, spheronization, and drying. Finally, Eudragit

was spray coated to preserve dried live probiotics from acid. An efficient disintegration of

spheres for fast and complete probiotic release in the intestine was maintained due to presence

of MCC and sodium alginate [149]. Prebiotics, which are known as non-digestible food

ingredients, are also used in probiotic delivery systems for enhancing the efficiency of acidic

protection and targeted probiotic delivery, as well as enhancing the growth of specific

beneficial bacteria in the intestine [150-152]. Galactooligosaccharide and inulin

(fructooligosachharide) are two common examples of prebiotics. Sathyabama et al. coencapsulated probiotics (Staphylococcus succinus) and prebiotics (inulin-containing chicory)

in alginate beads and demonstrated increased viability for the probiotic cells after exposure to 
ovalbumin was lyophilized and pressed to make the mini-tablet. Then, minitablets were coated

by either Lactose or Eudragit S100. Finally, the two coated minitablets were compressed to 2 form the BMTTS. This model has shown a high dual (intestine and colon) target-specific 3 delivery[154]. Another technique is to decrease the cell permeability via engineering the 4 surface of probiotic cell [155]. Polyelectrolytes such as chitosan and carboxymethyl cellulose 5 have also shown good potential for encapsulation of probiotics, thanks to their impermeability 6 to large enzyme molecules such as pepsin and pancreatin. Such polyelectrolytes can be used 7 for colon target delivery due to their role in increasing the stability in gastric and intestinal 8 $\mathrm{pH}[156]$. A study on the encapsulation of Saccharomyces boulardii by chitosan/dextran sulfate 9 multilayer polyelectrolytes has shown that the coated probiotic cells indicated a higher viability of $4.59 \pm 1.52 \log \mathrm{CFU} / 100 \mathrm{mg}$ compared to $1.90 \pm 0.80 \log \mathrm{CFU} / 100 \mathrm{mg}$ of uncoated probiotic cells in a simulated intestinal fluid (SIF) [157]. In another study, a tablet was designed based on hydroxypropyl methylcellulose phthalate (HPMCP) to protect probiotics at low $\mathrm{pH}$ $(\mathrm{pH} 1.5)$ and to deliver them in the upper $\mathrm{SI}(\mathrm{pH}$ ). The results showed a slower disintegration time and higher bacterial cell viability in the simulated GI fluid for the tablets prepared by high compression force[158]. Adding sodium alginate as a swelling agent into the tablets formula has been another technique to increase cell survival and reduce the disintegration time $[109,158,159]$. Tablet formulations containing 18 hydroxypropylmethylcellulose acetate succinate (HPMCAS) have been developed for delivery of L. acidophilus. It was shown that optimum gastric juice resistance was maintained by tablets containing HPMCAS and sodium alginate [160]. Carboxymethyl high amylose starch (CMHAS) was also proposed as an excipient for delivery of the Gram-negative Escherichia coli (E. 
an ionic self-stabilization carboxylated polymer (carboxymethyl high amylose starch, CM- 1 HAS) was also suggested for colon delivery of L. rhamnosus[162]. In another investigation, 2 succinylated beta-lactoglobulin was used as a novel tablet excipient to protect probiotics from 3 gastric juice and to deliver them to the intestine. Succinylation was shown to modify the 4 physico-chemical properties of beta-lactoglobulin and led to viability of up to $10^{8}$ and $10^{7} \mathrm{CFU} \quad 5$ after 1 and 2 hour incubation respectively. Native-lactoglobulin did however not protect $B$. 6 longum within acidic gastric fluid [34]. Additionally, electrospinning has several advantages 7 such as enhanced surface area to volume ratio leading to higher immobilization efficiency, 8 flexibility in selection of encapsulant, and enabling one-step procedure of drying of probiotics 9 to form a solid dosage [123, 163]. For instance, Fung et al. used soluble dietary fiber (SDF) 10 extracted from agrowastes, oil palm trunk (OPT), okara (soybean solid waste), and oil palm 11 frond (OPF), for encapsulation of L. acidophilus. Activated cells of L. acidophilus FTDC 8933 were cultured, centrifuged and were incorporated into the spinning solution to prepare 13 probiotic-loaded fiber, resulting 229-703 $\mathrm{nm}$ in diameter. These nanofibers showed a 14 survivability of 78.6-90\% in the electrospinning conditions [117]. Zupančič et al extracted the 15 strain 25.2.M from the oral microbiota of healthy volunteers. The strain was identified as 16 Bacillus sp., which may produce antimicrobial substances, and can overgrow the periodontal pathogen Aggregatibacter actinomycetemcomitans. They incorporated the strain into 18 nanofibers (chitosan/PEO (poly (ethylene oxide)) or PEO alone) with viability of $10^{7} \mathrm{CFU} / \mathrm{mg}$. The authors showed that the survival of the bacteria experienced a small change of 1 log unit 20 both during electrospinning and after 12 months of storage. The results indicated that CS/PEO nanofibers preserve the probiotics entrapped in the polymer matrix for longer time and the strain 25.2.M released by the fibers showed the potential for improving periodontal disease[164]. Coaxial electrospinning is an option for encapsulation and controlled release of biologically active agents[165]. Such a system has an advantage over normal electrospinning 
that the core material can include a favorable fluid medium, which does not have to be 1 spinnable as it becomes entrained by the outer polymeric shell[166]. In the study of Lo'pez- 2 Rubio et al, active bifidobacteria (B. animalis $\mathrm{Bb12}$ ) was encapsulated in ultrathin poly (vinyl 3 alcohol) $\mathrm{PVOH}$ electrospun fibers. In brief, B. animalis Bb12 cells were collected by 4 centrifugation, re-suspended in skimmed milk, and were pumped by the inner needle (L $0.8 \quad 5$ $\mathrm{mm}$ ) of the electrospinning setup. At the same time, the fiber forming polymer solution 6 (PVOH) was pumped by the outer needle (L $1.5 \mathrm{~mm}$ ). It was observed that B. animalis Bb12 7 survived within the PVOH electrospun fibers for 40 days at room temperature, and for $130 \quad 8$ days at refrigeration conditions. However, the survival of free Bb12 reduced significantly at 9 both temperatures. Some images of active bacteria-loaded electrospun nanofibers are shown in 10 Figure 6. More examples on use of polymeric carriers for delivery of probiotics are listed in 11 Table 2. 
Table 2: Polymeric carriers for encapsulation and delivery of probiotics

\begin{tabular}{|c|c|c|c|c|c|c|}
\hline $\begin{array}{l}\text { Product form/ } \\
\text { applied Carrier }\end{array}$ & Probiotic type & $\begin{array}{c}\text { Form of applied } \\
\text { bacteria }\end{array}$ & $\begin{array}{c}\text { Encapsulation } \\
\text { technique }\end{array}$ & $\begin{array}{l}\text { In vitro } \\
\text { or in vivo }\end{array}$ & Summary of the outcomes & Ref. \\
\hline $\begin{array}{l}\text { Chitosan-coated } \\
\text { alginate capsules }\end{array}$ & $\begin{array}{l}\text { Bifidobacterium } \\
\text { breve }\end{array}$ & $\begin{array}{l}\text { Live active } \\
\text { bacteria }\end{array}$ & $\begin{array}{l}\text { Layer-by-layer coating } \\
\text { (LBL) }\end{array}$ & In vitro & $\begin{array}{ll}\checkmark & \text { Gradual release of the probiotic during } 240 \text { minutes } \\
\checkmark & \text { Highest recovery of viable cells for 3-layer coated matrix } \\
\checkmark & \text { Increased viability from }<3 \text { log (colony-forming units } \\
& (\mathrm{CFU}) / \mathrm{ml} \text { (for free probiotic cells) to } 8.84 \pm 0.17 \\
& \log (\mathrm{CFU}) / \mathrm{mL} \text { (for the 3-layer coated matrix) }\end{array}$ & [128] \\
\hline $\begin{array}{l}\text { Chitosan-coated } \\
\text { alginate } \\
\text { microcapsules }\end{array}$ & $\begin{array}{l}\text { Bifidobacterium } \\
\text { breve }\end{array}$ & $\begin{array}{l}\text { Live active } \\
\text { bacteria }\end{array}$ & $\begin{array}{l}\text { 1) External gelation to } \\
\text { prepare alginate } \\
\text { microcapsules } \\
\text { 2) Coating with the } \\
\text { Bifidobacterium } \\
\text { breve -loaded } \\
\text { chitosan solution } \\
\text { 3) } \begin{array}{l}\text { Drying by fluid bed } \\
\text { drying method }\end{array}\end{array}$ & In vitro & $\begin{array}{l}\checkmark \text { Chitosan stabilized the alginate microcapsules at } \mathrm{pH}>3 \\
\checkmark \text { Chitosan coating enhanced the survival of } \\
\text { Bifidobacterium breve in simulated gastric fluid } \\
\checkmark \text { Chitosan prolonged the probiotic release in exposure to } \\
\text { intestinal pH }\end{array}$ & {$[38]$} \\
\hline $\begin{array}{ll}\text { Whey } & \text { protein- } \\
\text { coated } & \text { alginate } \\
\text { beads } & \end{array}$ & $\begin{array}{l}\text { Lactobacillus } \\
\text { plantarum spp }\end{array}$ & Freeze-dried & $\begin{array}{l}\text { 1) Suspension of the } \\
\text { probiotics in } \\
\text { sodium alginate } \\
\text { 2) Cold gelation of } \\
\text { alginate in the } \\
\text { presence of calcium } \\
\text { chloride }\left(\mathrm{CaCl}_{2}\right) \\
\text { solution. } \\
\text { 3) Coating by native } \\
\text { whey proteins. }\end{array}$ & In vitro & $\begin{array}{l}\checkmark \quad \text { Whey protein coating improved significantly the bacterial } \\
\text { survival in alginate beads. } \\
\checkmark \quad \text { Higher viability of the encapsulated probiotics in the } \\
\text { gastric environment compared with free probiotics. }\end{array}$ & {$[167]$} \\
\hline $\begin{array}{l}\text { Coating alginate by } \\
\text { poly-l-lysine (PLL) } \\
\text { to make alginate-PA } \\
\text { (AP) microparticles }\end{array}$ & $\begin{array}{l}\text { Bifidobacterium } \\
\text { bifidum }(\mathrm{BB})\end{array}$ & Freeze-dried & $\begin{array}{l}\text { 1) Spraying } \\
\text { bifidobacteria- } \\
\text { alginate mixture } \\
\text { into } \mathrm{CaCl}_{2} \text { solution }\end{array}$ & In vitro & $\begin{array}{l}\checkmark \quad \text { The viability of bifidobacteria was significantly increased } \\
\text { at low pH conditions } \\
\checkmark \quad \text { Preserved their viability up to } 10^{7} \mathrm{cfu} / \mathrm{g} \text { during } 16 \text { weeks } \\
\text { storage at } 4^{\circ} \mathrm{C} \text {. }\end{array}$ & {$[130]$} \\
\hline
\end{tabular}




\begin{tabular}{|c|c|c|c|c|c|c|}
\hline & & & $\begin{array}{l}\text { using air atomizing } \\
\text { device } \\
\text { 2) Suspending the } \\
\text { microgel droplets in } \\
\text { PLL solution } \\
\text { 3) Freeze-drying to get } \\
\text { final microparticles }\end{array}$ & & $\begin{array}{l}\text { Smaller size microparticles could be used for different } \\
\text { dairy products without significant loss of viability under } \\
\text { the low pH conditions }\end{array}$ & \\
\hline $\begin{array}{l}\text { Coating alginate by } \\
\text { PLL and again by } \\
\text { alginate to make } \\
\text { alginate-PLL- } \\
\text { alginate (APA) } \\
\text { microcapsules }\end{array}$ & $\begin{array}{l}\text { Lactobacillus } \\
\text { plantarum } 80 \\
\text { (LP80) }\end{array}$ & $\begin{array}{ll}\text { Live } & \text { active } \\
\text { bacteria } & \end{array}$ & 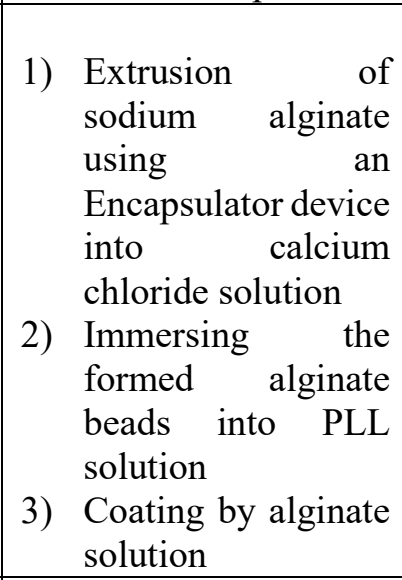 & In vitro & $\begin{array}{l}\checkmark \quad 80 \% \text { of encapsulated LP80 microcapsules remained } \\
\text { viable after } 5 \text { min exposure to SGF } \\
\checkmark \quad \text { The viability lowered to } 2.6 \% \text { after } 30 \text { min and about } \\
0.2 \% \text { after } 60 \text { min. } \\
\checkmark \quad \text { The APA microcapsules kept their physical stability in } \\
\text { acidic condition, but their structure was destroyed by } \\
\text { increasing the pH. }\end{array}$ & {$[168]$} \\
\hline AP microparticles & $\begin{array}{l}\text { Bifidobacterium } \\
\text { bifidum (BB) }\end{array}$ & Freeze-dried & $\begin{array}{l}\text { 1) Air atomization } \\
\text { method } \\
\text { 2) } \begin{array}{l}\text { Crosslinking by } \\
\text { poly-l-lysine } \\
\text { solution }\end{array} \\
\end{array}$ & $\begin{array}{l}\text { In vivo/ } \\
\text { Human } \\
\text { volunteers }\end{array}$ & $\begin{array}{l}\checkmark \text { BB-loaded AP microparticles enhanced the survival of } \\
\text { bifidobacteria in human volunteers (approximately } 11.5 \\
\text { to } 30 \text { times) in comparison with free BB probiotic. } \\
\checkmark \text { Oral delivery of BB-loaded AP microparticles can be used } \\
\text { in the acidic stomach condition in humans }\end{array}$ & {$[131]$} \\
\hline APA microcapsules & $\begin{array}{l}\text { Lactobacillus } \\
\text { acidophilus }\end{array}$ & $\begin{array}{ll}\text { Live } & \text { active } \\
\text { bacteria } & \end{array}$ & $\begin{array}{l}\text { Inotech Encapsulator }{ }^{\circledR} \\
\text { IER-20 }\end{array}$ & $\begin{array}{l}\text { In } \\
\text { vivo/mice }\end{array}$ & $\begin{array}{l}\text { Oral administration of Lactobacillus acidophilus- loaded } \\
\text { microcapsules significantly helped with reducing the } \\
\text { tumor size and prevention of colon tumor incidence. }\end{array}$ & {$[133]$} \\
\hline APA microcapsules & $\begin{array}{l}\text { Lactobacillus } \\
\text { plantarum } 80\end{array}$ & $\begin{array}{l}\text { Live active } \\
\text { bacteria }\end{array}$ & $\begin{array}{l}\text { 1) Extrusion } \\
\text { 2) Coating with PLL }\end{array}$ & In vitro & 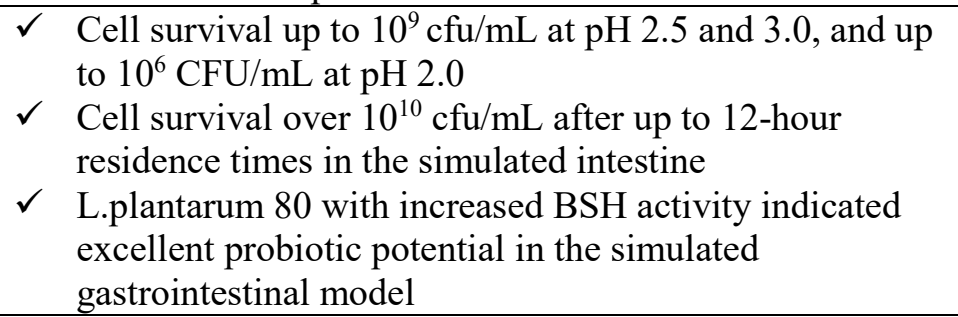 & {$[132]$} \\
\hline
\end{tabular}




\begin{tabular}{|c|c|c|c|c|c|c|}
\hline $\begin{array}{l}\text { Multilayer } \\
\text { microcapsules of } \\
\text { APPPA (alginate } \\
\text { Polylysine- } \\
\text { pectinate- } \\
\text { Polylysine-alginate) }\end{array}$ & $\begin{array}{l}\text { Lactobacillus } \\
\text { reuteri }\end{array}$ & Not mentioned & $\begin{array}{l}\text { 1) Extrusion (an } \\
\text { Inotech } \\
\text { encapsulator IER- } \\
\text { 20) } \\
\text { 2) } \\
\text { coating by } \\
\text { solutions of PLL, } \\
\text { pectin and alginate }\end{array}$ & In vitro & $\begin{array}{ll}\checkmark & \text { Better GI stability of APPPA compared with APA } \\
\checkmark & \text { L. reuteri-loaded APPPA were not damaged at pH 1, 3, } \\
5,7 \text {, and } 9 \text { after exposure to SGF and SIF for } 3 \mathrm{~h} \text { with } \\
250 \mathrm{rpm} \text { shaking at } 37.2^{\circ} \mathrm{C} \text {. }\end{array}$ & [136] \\
\hline $\begin{array}{l}\text { Alginate or chitosan } \\
\text { beads } \\
\text { functionalized by } \\
\text { succinylation or } \\
\text { acylation }\end{array}$ & $\begin{array}{l}\text { Lactobacillus } \\
\text { rhamnosus }\end{array}$ & freeze-dried & $\begin{array}{l}\text { Dropping the } \\
\text { suspension of } \\
\text { functionalized } \\
\text { polymers containing } \\
\text { the probiotics into the } \\
\mathrm{CaCl}_{2} \text { solution to make } \\
\text { beads }\end{array}$ & In vitro & $\begin{array}{l}\checkmark \text { The most viability and protection for the probiotic } \\
\text { loaded in N-palmitoylaminoethyl alginate. } \\
\checkmark \text { No significant difference in protection of encapsulated } \\
\text { cells between Succinylated alginate and succinylated } \\
\text { chitosan beads. }\end{array}$ & {$[138]$} \\
\hline $\begin{array}{l}\text { Alginate-chitosan- } \\
\text { alginate (ACA) } \\
\text { microcapsules }\end{array}$ & $\begin{array}{l}\text { Escherichia coli } \\
\text { DH5 }\end{array}$ & Live active cells & $\begin{array}{l}\text { 1) Extrusion to } \\
\text { prepare Ca-alginate } \\
\text { beads } \\
\text { 2) } \begin{array}{l}\text { Transfer to chitosan } \\
\text { solution }\end{array}\end{array}$ & $\begin{array}{l}\text { In vitro } \\
\text { and in } \\
\text { vivo }\end{array}$ & $\begin{array}{l}\text { Higher stability of ACA than APA microcapsule } \\
\text { resulting in increased resistance to GI enzymatic } \\
\text { degradation }\end{array}$ & [137] \\
\hline $\begin{array}{l}\text { Microcapsules from } \\
\text { mixture of alginate } \\
\text { and modified starch }\end{array}$ & $\begin{array}{l}\text { Lactobacillus } \\
\text { acidophilus and } \\
\text { Bifidobacterium } \\
\text { lactis }\end{array}$ & Freeze-dried & Emulsification & $\begin{array}{l}\text { Storage } \\
\text { test in } \\
\text { yoghurt }\end{array}$ & $\begin{array}{l}\checkmark \quad \text { Enhanced survival of } 1 \text { and } 2 \text { log cell numbers of B. } \\
\text { lactis and L. acidophilus respectively. } \\
\checkmark \quad \text { More storage viability for encapsulated probiotics } \\
\text { compared to free cells }\end{array}$ & [142] \\
\hline $\begin{array}{l}\text { CAP beads with } \\
\text { Core-shell } \\
\text { structure: CAP (Ca- } \\
\text { alginate/protamine } \\
\text { composite) as shell, } \\
\text { (CA) } \\
\text { (Lactobacillus- } \\
\text { casei-encapsulated } \\
\text { Ca-alginate as core }\end{array}$ & $\begin{array}{l}\text { Lactobacillus } \\
\text { casei }\end{array}$ & $\begin{array}{l}\text { Live active cell } \\
\text { Lactobacillus } \\
\text { casei CICC } \\
23185\end{array}$ & 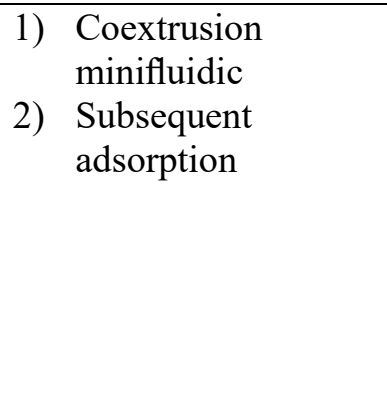 & In vitro & $\begin{array}{ll}\checkmark & \text { fast release of Lactobacillus casei in small intestine } \\
\checkmark & \text { Improved protection for Lactobacillus casei in the } \\
\text { stomach } \\
\checkmark & \text { CAP beads showed significant pH-responsive } \\
\text { protection }\end{array}$ & [143] \\
\hline
\end{tabular}




\begin{tabular}{|c|c|c|c|c|c|c|}
\hline $\begin{array}{l}\text { Polymer film } \\
\text { Laminate (PFL) } \\
\text { including a blend of } \\
\text { ethylcellulose and } \\
\text { Eudragit }\end{array}$ & $\begin{array}{l}\text { Bifidobacterium } \\
\text { breve }\end{array}$ & $\begin{array}{l}\text { Live active } \\
\text { Bifidobacterium } \\
\text { breve NCIMB } \\
8807\end{array}$ & $\begin{array}{l}\text { 1) Casting of polymer } \\
\text { films by solvent } \\
\text { evaporation } \\
\text { 2) Drying bacteria } \\
\text { onto the cast } \\
\text { enteric polymer } \\
\text { films }\end{array}$ & In vitro & $\begin{array}{l}\checkmark \text { Ethylcellulose plus Eudragit provides more protection } \\
\text { in acidic condition, compared to Eudragit alone. }\end{array}$ & [147] \\
\hline $\begin{array}{l}\text { Microparticles from } \\
\text { incorporating } \\
\text { PLGA } \\
\text { containing prebiotic } \\
\text { Bimuno }^{\mathrm{TM}} \text { into } \\
\text { alginate-chitosan } \\
\text { matrix containing } \\
\text { Bifidobacterium } \\
\text { breve }\end{array}$ & $\begin{array}{l}\text { A synbiotic } \\
\text { including } \\
\text { prebiotic } \\
\text { Bimuno }^{\mathrm{TM}} \text { and } \\
\text { probiotic } \\
\text { Bifidobacterium } \\
\text { breve. }\end{array}$ & $\begin{array}{l}\text { Live active } \\
\text { Bifidobacterium } \\
\text { breve NCIMB } \\
8807\end{array}$ & $\begin{array}{l}\text { 1) Adding aqueous } \\
\text { BiMunoTM } \\
\text { solution of to } \\
\text { PLGA solution } \\
\text { 2) Adding the } \\
\text { emulsion from step } \\
1 \text { into aqueous } \\
\text { alginate solution to } \\
\text { have a } \\
\text { water/oil/water } \\
\text { (WOW) emulsion } \\
\text { 3) Freeze-drying }\end{array}$ & In vitro & $\begin{array}{l}\text { Controlled release of prebiotics by synbiotic } \\
\text { multiparticulate during in vitro GI transit increased } \\
\text { survival of cells in acid, and improved encapsulation of } \\
\text { B. breve in alginate- chitosan microcapsules } \\
\checkmark \quad \begin{array}{l}\text { Hydrophobicity of PLGA particles assisted with } \\
\text { controlled release and increased survival. }\end{array}\end{array}$ & [169] \\
\hline $\begin{array}{l}\text { Alginate beads } \\
\text { including both } \\
\text { probiotics and } \\
\text { prebiotics }\end{array}$ & $\begin{array}{l}\text { Probiotics: } \\
\text { Enterococcus } \\
\text { fecium (FIdM3) } \\
\text { and } \\
\text { Staphylococcus } \\
\text { succinus } \\
\text { (MAbB4) } \\
\text { Prebiotics: } \\
\text { sugarbeet and } \\
\text { chicory }\end{array}$ & $\begin{array}{l}\text { Live active cells } \\
\text { were isolated } \\
\text { from human } \\
\text { fecal samples }\end{array}$ & $\begin{array}{l}\text { Forming the beads by } \\
\text { dropping an emulsified } \\
\text { mixture to a } \mathrm{CaCl}_{2} \\
\text { solution }\end{array}$ & In vitro & $\begin{array}{l}\checkmark \text { An increased viability was received for the probiotic } \\
\text { cells by encapsulation of alginate beads with chicory and } \\
\text { Staphylococcus succinus } \\
\checkmark \quad \text { Improved viability for co-encapsulated cells after } \\
\text { exposure to acidic and bile conditions. } \\
\checkmark \quad 98.75-88.75 \% \text { of survivability was seen for the } \\
\text { encapsulated cells in the simulated gastric environment }\end{array}$ & [153] \\
\hline
\end{tabular}




\begin{tabular}{|c|c|c|c|c|c|c|}
\hline $\begin{array}{l}\text { Microcapsules of } \\
\text { RSM (reconstituted } \\
\text { skim milk) mixed } \\
\text { with either of the } \\
\text { prebiotics: inulin, } \\
\text { oligofructose or } \\
\text { oligofructose- } \\
\text { enriched inulin }\end{array}$ & $\begin{array}{l}\text { Bifidobacterium } \\
\text { BB-12 }\end{array}$ & Freeze-dried & Spray drying & In vitro & $\begin{array}{l}\text { Better protection of bacteria when blending of RSM } \\
\text { with oligofructose-enriched inulin or RSM with } \\
\text { oligofructose was used } \\
\checkmark \quad \begin{array}{l}\text { More stability of the microcapsules prepared with } \\
\text { prebiotics }\end{array}\end{array}$ & {$[170]$} \\
\hline $\begin{array}{l}\text { ovalbumin bi- } \\
\text { layered mini-tablet- } \\
\text { in-tablet system } \\
\text { (BMTTS) }\end{array}$ & $\begin{array}{l}\text { Lactobacillus } \\
\text { acidophilus }\end{array}$ & Freeze-dried & $\begin{array}{l}\text { Mini-Tablet } \\
\text { Press (compression } \\
\text { coating) }\end{array}$ & In vitro & $\begin{array}{l}\text { Effectiveness of BMTTSs in protection and delivery of } \\
\text { probiotic L. acidophilus to both simulated intestine and } \\
\text { colon due to two different coatings by Lactose or } \\
\text { Eudragit S100. }\end{array}$ & {$[154]$} \\
\hline $\begin{array}{l}\text { Tablets containing } \\
\text { different polymers } \\
\text { in formula: } \\
\text { 1: methocel K-15- } \\
\text { sodium alginate; } 2 \text { : } \\
\text { Eudragit1-alginate; } \\
\text { 3: cellulose acetate } \\
\text { phthalate) }\end{array}$ & $\begin{array}{l}\text { Lactobacillus } \\
\text { fermentum } \\
\text { CECT } 5716\end{array}$ & Freeze-dried & Direct compression & In vitro & 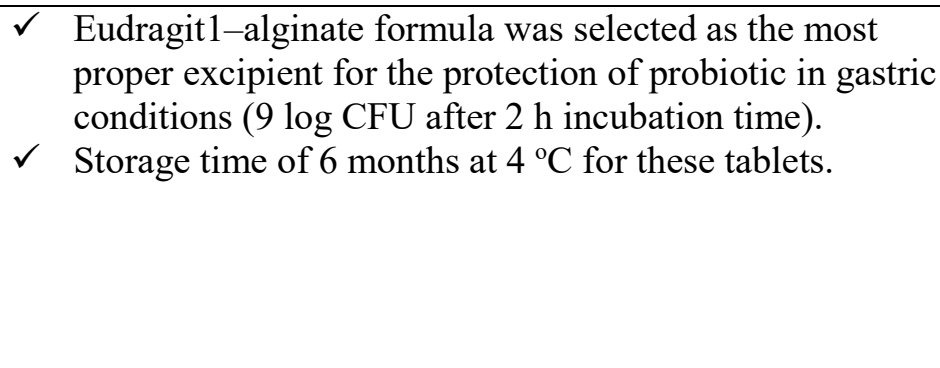 & {$[171]$} \\
\hline $\begin{array}{l}\text { Bio } \\
\text { nanocomposites } \\
\text { comprising BNC } \\
\text { (bacterial } \\
\text { nanocellulose), } \\
\text { pectin and } \\
\text { Schizophyllum } \\
\text { commune }\end{array}$ & $\begin{array}{l}\text { Bacillus } \\
\text { coagulans }\end{array}$ & $\begin{array}{l}\text { Live active } \\
\text { bacteria }\end{array}$ & $\begin{array}{l}\text { 1) Mixing of bio } \\
\text { nanocomposite and } \\
\text { the probiotic, } \\
\text { 2) Drying }\end{array}$ & In vitro & $\begin{array}{l}\checkmark \text { High viability of B. coagulans after microwave drying } \\
(99.43 \%) \text { and degradation under stimulated } \\
\text { gastrointestinal fluids }(94.76 \%) \text { Bionanocomposite } \\
\text { including } 57 \% \text { BNC and } 43 \% \text { pectin protected B. } \\
\text { coagulans cells against thermal drying and GI tract } \\
\text { condition } \\
\checkmark \text { BNC presence in the formulation of the bio } \\
\text { nanocomposite improved stability of B. coagulans at } \\
\text { different temperatures in long-term storage }\end{array}$ & {$[172]$} \\
\hline
\end{tabular}




\begin{tabular}{|c|c|c|c|c|c|c|}
\hline $\begin{array}{l}\text { Layered structure } \\
\text { including } \\
\text { polyelectrolytes of } \\
\text { (CHI) chitosan and } \\
\text { CMC } \\
\text { (carboxymethyl } \\
\text { cellulose) }\end{array}$ & $\begin{array}{l}\text { Lactobacillus } \\
\text { acidophilus }\end{array}$ & Freeze-dried & $\begin{array}{l}\text { Electrostatic self- } \\
\text { assembly of } \\
\text { polyelectrolytes }\end{array}$ & In vitro & $\begin{array}{l}\text { The probiotic L. acidophilus coated with three } \\
\text { polyelectrolyte layers of CHI/CMC/CHI indicated a } \\
\text { survival about } 33 \log \% \text { of the cells }(6 \log \text { cfu } / 500 \mathrm{mg}) \\
\text { while all free probiotic cells died at the same conditions. } \\
\checkmark \quad \text { The layered structure showed stability in the gastric } \\
\text { environment }\end{array}$ & [156] \\
\hline $\begin{array}{l}\text { Alginate/ } \\
\text { polydopamine } \\
\text { core/shell } \\
\text { microcapsules }\end{array}$ & $\begin{array}{l}\text { Saccharomyces } \\
\text { cerevisiae }\end{array}$ & $\begin{array}{l}\text { Live active } \\
\text { bacteria }\end{array}$ & $\begin{array}{l}\text { 1) Probiotic- } \\
\text { containing } \\
\text { suspension was } \\
\text { pumped into the } \\
\mathrm{CaCl}_{2} \text { solution } \\
\text { 2) Dopamine } \\
\text { hydrochloride was } \\
\text { added to the } \\
\text { solution including } \\
\text { Cell-laden beads }\end{array}$ & In vitro & $\begin{array}{l}\text { Polydopamine coating increased mechanical stability of } \\
\text { alginate beads, prevented cell leakage for more than } 25 \mathrm{~h} \\
\text { in the presence of monovalent ions, and prevented from } \\
\text { bead swelling and UV radiation }\end{array}$ & [124] \\
\hline $\begin{array}{l}\text { Enteric coated } \\
\text { spheres (Eudragit } \\
\text { coating of a mixture } \\
\text { of MCC } \\
\text { (microcrystalline } \\
\text { cellulose), alginate } \\
\text { and lactose) }\end{array}$ & $\begin{array}{l}\text { Lactobacillus } \\
\text { casei }\end{array}$ & $\begin{array}{l}\text { Live active } \\
\text { Lactobacillus } \\
\text { casei NCIMB } \\
30185 \text { (PXN 37) }\end{array}$ & $\begin{array}{l}\text { 1) Granulation } \\
\text { 2) Extrusion } \\
\text { 3) Spheronization } \\
\text { 4) Drying } \\
\text { 5) Spray coating }\end{array}$ & In vitro & $\begin{array}{ll} & 10^{8} \text { CFU of probiotic released after } 2 \mathrm{~h} \text { exposure to SGF } \\
\text { and } 1 \mathrm{~h} \text { exposure to SIF and } \\
\checkmark \quad \text { No significant loss of viability in all steps except drying } \\
\text { (1 log loss of viable cells) }\end{array}$ & [148] \\
\hline $\begin{array}{l}\text { Chitosan/ } \\
\text { dextran sulfate } \\
\text { multilayer } \\
\text { polyelectrolytes }\end{array}$ & $\begin{array}{l}\text { Saccharomyces } \\
\text { boulardii }\end{array}$ & $\begin{array}{l}\text { S. boulardii } \\
\text { powder }\end{array}$ & $\begin{array}{l}\text { layer-by-layer assembly } \\
\text { of oppositely charged } \\
\text { Polyelectrolytes }\end{array}$ & In vitro & 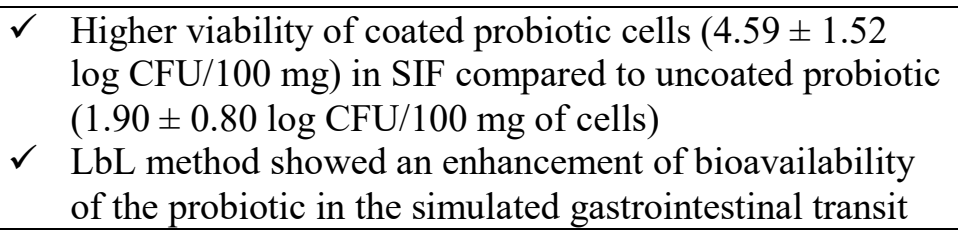 & [157] \\
\hline $\begin{array}{l}\text { Microcapsules } \\
\text { made from } \\
\text { Prebiotics } \\
\text { (fructooligosacchari }\end{array}$ & $\begin{array}{l}\text { Lactobacillus } \\
\text { acidophilus; } \\
\text { Lactobacillus } \\
\text { casei; }\end{array}$ & Freeze-dried & $\begin{array}{l}\text { Extrusion of the cell } \\
\text { suspension into } \mathrm{CaCl}_{2} \\
\text { solution }\end{array}$ & In vitro & $\begin{array}{l}\text { Mixture of } 1 \% \text { sodium alginate, } 1 \% \text { peptide, and 3\% } \\
\text { fructooligosaccharide produced the highest survival for } \\
\text { the probiotic. }\end{array}$ & [121] \\
\hline
\end{tabular}




\begin{tabular}{|c|c|c|c|c|c|c|}
\hline $\begin{array}{l}\text { de or } \\
\text { isomaltooligosacch } \\
\text { arides), growth } \\
\text { promoter (peptide), } \\
\text { and sodium alginate }\end{array}$ & $\begin{array}{l}\text { Bifidobacterium } \\
\text { bifidum; and } \\
\text { Bifidobacterium } \\
\text { longum) }\end{array}$ & & & & $\begin{array}{l}\checkmark \quad \text { In storage experiment, addition of prebiotics in the walls } \\
\text { of probiotic microcapsules enhanced the protection. } \\
\checkmark \quad 10^{6} \text { to } 10^{7} \text { (CFU)/g viability in microcapsules after } 1 \\
\text { month of storage. }\end{array}$ & \\
\hline $\begin{array}{l}\text { Cellulose acetate } \\
\text { phthalate } \\
\text { (CAP)microspheres }\end{array}$ & $\begin{array}{l}\text { Bifidobacterium } \\
\text { pseudolongum }\end{array}$ & Freeze-dried & $\begin{array}{l}\text { Phase separation- } \\
\text { coacervation }\end{array}$ & In vitro & $\begin{array}{l}\checkmark \text { Microencapsulated B. pseudolongum showed more } \\
\text { survival }\left(10^{9} \mathrm{cfu} / \mathrm{mL}\right) \text { in the simulated gastric condition } \\
\text { than non-encapsulated B. pseudolongum. }\end{array}$ & {$[173]$} \\
\hline $\begin{array}{l}\text { Polysaccharide- } \\
\text { Protein gel beads } \\
\text { including alginate, } \\
\text { pectin and whey } \\
\text { proteins }\end{array}$ & $\begin{array}{l}\text { B. bifidum } \\
\text { RO71 }\end{array}$ & Freeze-dried & $\begin{array}{l}\text { 1) Immobilization } \\
\text { procedure (Sodium } \\
\text { alginate, pectin, } \\
\text { and whey protein); } \\
\text { 2) } \begin{array}{l}\text { Formation of gel } \\
\text { beads (by a syringe }\end{array} \\
\text { equipped with a } \\
\text { needle); } \\
\text { 3) Transacylation } \\
\text { reaction to form } \\
\text { membranes }\end{array}$ & In vitro & 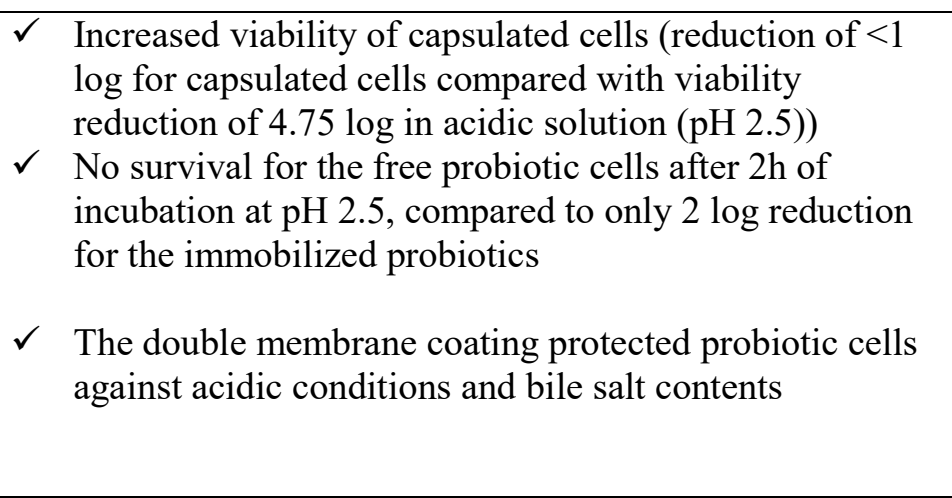 & [174] \\
\hline $\begin{array}{l}\text { Chitosan-coated } \\
\text { alginate } \\
\text { microcapsules } \\
\text { (CCAMs) }\end{array}$ & $\begin{array}{l}\text { Lactobacillus } \\
\text { acidophilus }\end{array}$ & Freeze-dried & $\begin{array}{l}\text { Inotech encapsulator } \\
\text { IER-20 }\end{array}$ & In vitro & $\begin{array}{l}\checkmark \text { L.acidophilus-loaded CCAMs added to yogurt } \\
\text { represented higher viability in comparison with free cells } \\
\text { suspended in yogurt. } \\
\checkmark \quad \text { The encapsulated probiotic can be viable more than the } \\
\text { non-encapsulated probiotic and even yogurt-inherent } \\
\text { probiotic cells in both SGF and SIF }\end{array}$ & [129] \\
\hline $\begin{array}{l}\text { Genipin cross- } \\
\text { linked chitosan- } \\
\text { coated alginate } \\
\text { (GCCA) } \\
\text { microcapsules }\end{array}$ & $\begin{array}{l}\text { Lactobacillus } \\
\text { plantarum } 80 \\
\mathrm{P}(\mathrm{CBH} 1) \\
(\mathrm{LP} 80) \\
\text { mammalian } \\
\text { HepG2 cells }\end{array}$ & $\begin{array}{l}\text { Live active } \\
\text { bacteria }\end{array}$ & $\begin{array}{l}\text { Encapsulator } \\
\text { (Inotech. Corp.) }\end{array}$ & In vitro & $\begin{array}{l}\checkmark \text { LP80-loaded GCCA microcapsules successfully } \\
\text { preserved the encapsulated live probiotics during long- } \\
\text { term storage. } \\
\checkmark \quad \text { Probiotic cells viability was maintained } 6 \text { months post } \\
\text { encapsulation. } \\
\checkmark \quad \text { Metabolic activity of the encapsulated HepG2 indicated } \\
\text { the potential capacity of these GCAC microcapsules in } \\
\text { cell therapy }\end{array}$ & [175] \\
\hline
\end{tabular}




\begin{tabular}{|c|c|c|c|c|c|c|}
\hline $\begin{array}{l}\text { Alginate, xanthan, } \\
\text { carrageenan, guar, } \\
\text { or locust gum } \\
\text { microcapsules }\end{array}$ & $\begin{array}{l}\text { Ten probiotics } \\
\text { bacteria such as } \\
\text { Lactobacillus } \\
\text { rhamnosus, } \\
\text { Bifidobacterium } \\
\text { longum, L. etc. }\end{array}$ & $\begin{array}{l}\text { Live active } \\
\text { bacteria }\end{array}$ & Emulsion & In vitro & $\begin{array}{l}\checkmark \text { The encapsulated bacteria indicated a remarkable higher } \\
\text { survival rate than free bacteria under acidic condition. } \\
\checkmark \quad \text { The viability of the free probiotic cells was reduced by } \\
6.63 \text { Log CFU/ml after exposure to taurocholic acid. } \\
\text { Lower reductions of 3.63, 3.27, and } 4.12 \text { Log CFU/ml } \\
\text { was observed in probiotic cells loaded in alginate, } \\
\text { xanthan gum, and carrageenan gum, respectively. } \\
\checkmark \quad \text { Xanthan gum and carrageenan showed to be as effective } \\
\text { as alginate to protect probiotics from harsh acidic } \\
\text { conditions. }\end{array}$ & {$[176]$} \\
\hline $\begin{array}{l}\text { PVA (poly(vinyl } \\
\text { alcohol) and } \\
\text { Agrowastes, okara } \\
\text { (soybean solid } \\
\text { waste), OPT (oil } \\
\text { palm trunk), and } \\
\text { OPF (oil palm } \\
\text { frond) fibers }\end{array}$ & $\begin{array}{l}\text { Lactobacillus } \\
\text { acidophilus }\end{array}$ & Freeze-dried & Electrospinning & In vitro & $\begin{array}{ll}\checkmark & \text { Survivability of } 78.6-90 \% \text { in the electrospinning } \\
\text { conditions } \\
\checkmark \quad \text { Viability preservation for } 21 \text { days at refrigeration } \\
\text { temperature }\end{array}$ & [117] \\
\hline $\begin{array}{l}\text { chitosan/PEO fibers } \\
\text { and PEO fibers }\end{array}$ & strain 25.2.M & $\begin{array}{l}\text { Live active } \\
\text { bacteria isolated } \\
\text { from the oral } \\
\text { microbiota of } \\
\text { healthy humans }\end{array}$ & Electrospinning & In vitro & $\begin{array}{l}\text { The viabilities were exceptional both during } \\
\text { electrospinning and after } 12 \text { months of storage (max. } \\
\text { change of } 1 \text { log unit). }\end{array}$ & [164] \\
\hline $\begin{array}{l}\text { Monolithic PEO } \\
\text { and composite } \\
\text { PEO/lyoprotectant } \\
\text { fibers }\end{array}$ & $\begin{array}{l}\text { Lactobacillus } \\
\text { plantarum }\end{array}$ & $\begin{array}{l}\text { Live active } \\
\text { bacteria of } \\
\text { Lactobacillus } \\
\text { plantarum ATCC } \\
8014\end{array}$ & Electrospinning & In vitro & $\begin{array}{l}\checkmark \text { These fibers provided a high loading of L. plantarum } \\
\text { cells (up to } 7.6 \times 10^{8} \mathrm{CFU} / \mathrm{mg} \text { ). } \\
\checkmark \quad \text { Adding of high amount of lyoprotectant to the composite } \\
\text { fibers provided little improvements in the L. plantarum } \\
\text { cell viabilities after the electrospinning, but large } \\
\text { viability advantages within storage. } \\
\checkmark \quad \text { The PEO fibers delivered all of the L. plantarum cells } \\
\text { during 30min that is suitable for their local } \\
\text { administration. }\end{array}$ & [123] \\
\hline
\end{tabular}




\begin{tabular}{|c|c|c|c|c|c|c|}
\hline $\begin{array}{l}\text { WPC (whey protein } \\
\text { concentrate), a } \\
\text { commercial } \\
\text { maltodextrin } \\
\text { (Fibersol } ® \text { ), } \\
\text { Polysaccharide } \\
\text { maltodextrin, Zein } \\
\text { and PVP } \\
\text { microparticles }\end{array}$ & $\begin{array}{l}\text { Bifidobacterium } \\
\text { longum subsp. } \\
\text { infantis }\end{array}$ & Freeze-dried & $\begin{array}{l}\text { Electrospray coating } \\
\text { atomization (ECA) }\end{array}$ & In vitro & $\begin{array}{l}\checkmark \quad \text { ECA is introduced as a novel method to protect dry } \\
\text { forms of probiotics } \\
\checkmark \quad \text { WPC, Fibersol® and PVP indicated the best survival } \\
\text { rates among applied polymers. } \\
\checkmark \quad \text { Cell viability of electrospray-coated samples were about } \\
6-1 \text { og cfu/g after } 600 \text { days at } 23 \% \text { RH and after } 10 \text { days } \\
\text { at } 37{ }^{\circ} \mathrm{C} \text { while non-coated could not survive in the } \\
\text { conditions. }\end{array}$ & {$[114]$} \\
\hline $\begin{array}{l}\text { Ultrathin poly } \\
\text { (vinyl alcohol) } \\
\text { PVOH } \\
\text { electrospun fibers }\end{array}$ & $\begin{array}{l}\text { Bifidobacterium } \\
\text { strains }\end{array}$ & $\begin{array}{l}\text { Live active cells } \\
\text { Bifidobacterium } \\
\text { animalis subsp. } \\
\text { lactis Bb12 }\end{array}$ & Coaxial electrospinning & In vitro & $\begin{array}{l}\checkmark \text { The strain animalis Bb12 survived in the PVOH } \\
\text { electrospun fibers for } 40 \text { days at room temperature and } \\
\text { for } 130 \text { days at refrigeration conditions, while the } \\
\text { survival of free animalis Bb12 reduced significantly at } \\
\text { both conditions. }\end{array}$ & {$[116]$} \\
\hline $\begin{array}{l}\text { Poly(vinyl alcohol) } \\
\text { (PVA) fibers }\end{array}$ & $\begin{array}{l}\text { Lactobacillus } \\
\text { gasseri }\end{array}$ & $\begin{array}{l}\text { Live active cells } \\
\text { L. gasseri } 3143 \\
\text { strain }\end{array}$ & Electrospinning & In vivo & $\begin{array}{l}\text { Good viability of encapsulated L. gasseri at }-70{ }^{\circ} \mathrm{C} \text { for } \\
\text { long-term storage and ineffectiveness of their } \\
\text { metabolism by immobilization confirmed their } \\
\text { application for food engineering and trade }\end{array}$ & {$[118]$} \\
\hline $\begin{array}{l}\text { Microcapsules of } \\
\text { WPC (whey protein } \\
\text { concentrate) or } \\
\text { Pullulan }\end{array}$ & $\begin{array}{l}\text { Bifidobacterium } \\
\text { animalis subsp. } \\
\text { lactis } \mathrm{Bb} 12\end{array}$ & $\begin{array}{l}\text { Live active cells } \\
\text { Bifidobacterium } \\
\text { animalis subsp. } \\
\text { lactis Bb12 }\end{array}$ & $\begin{array}{l}\text { Freeze-drying } \\
\text { /electrospraying }\end{array}$ & In vitro & $\begin{array}{ll}\checkmark & \text { WPC-based capsules confirmed a more cell viability } \\
\text { compared to pullulan- based capsules. } \\
\checkmark \\
\text { Electrosprayed encapsulation prolonged bifidobacteria } \\
\text { survival during storage at } 4 \text { and } 20{ }^{\circ} \mathrm{C} \text { and at different } \\
\text { relative humidities }(0,11,53 \text { and even } 75 \% \mathrm{RH}) .\end{array}$ & [49] \\
\hline $\begin{array}{l}\text { Microcapsules of (i) } \\
\text { WPI (Whey protein } \\
\text { isolate) with SA } \\
\text { (sodium alginate) } \\
\text { (ii) WPI with FOS } \\
\text { (fructooligosacchari } \\
\text { de) } \\
\text { (iii) DWPI } \\
\text { (denatured WPI) } \\
\text { with SA }\end{array}$ & $\begin{array}{l}\text { Lactobacillus } \\
\text { Plantarum }\end{array}$ & Freeze-dried & $\begin{array}{l}\text { Spray freeze drying } \\
\text { (SFD) method }\end{array}$ & In vitro & $\begin{array}{l}\checkmark \quad \text { Microencapsulation by SFD method maintained the cell } \\
\text { viability. } \\
\checkmark \quad \text { DWPI + FOS showed higher encapsulation efficiency } \\
\text { and more stability during storage }\end{array}$ & {$[122]$} \\
\hline
\end{tabular}




\begin{tabular}{|c|c|c|c|c|c|c|}
\hline $\begin{array}{l}\text { (iv) DWPI with } \\
\text { FOS }\end{array}$ & & & & & & \\
\hline $\begin{array}{l}\text { SFG } \\
\text { (starch- } \\
\text { formate/glycerol) } \\
\text { compound fibers }\end{array}$ & $\begin{array}{l}\text { Lactobacillus } \\
\text { paracasei }\end{array}$ & $\begin{array}{l}\text { Active live L. } \\
\text { paracasei }\end{array}$ & Coaxial electrospinning & In vitro & $\begin{array}{l}\text { L. paracasei-loaded SFG fibers can be considered as an } \\
\text { alternative route for the probiotic encapsulation and for } \\
\text { extended storage }\end{array}$ & [119] \\
\hline $\begin{array}{l}\text { Tablets including } \\
\text { HPMCP } \\
\text { (Hydroxypropyl } \\
\text { methylcellulose } \\
\text { phthalate) as the } \\
\text { main polymer. } \\
\text { Others: Sodium } \\
\text { alginate, apple } \\
\text { pectin, and } \\
\text { Metolose® }\end{array}$ & $\begin{array}{l}\text { Lactobacillus } \\
\text { fermentum } 2311\end{array}$ & Freeze-dried & Compression method & In vitro & 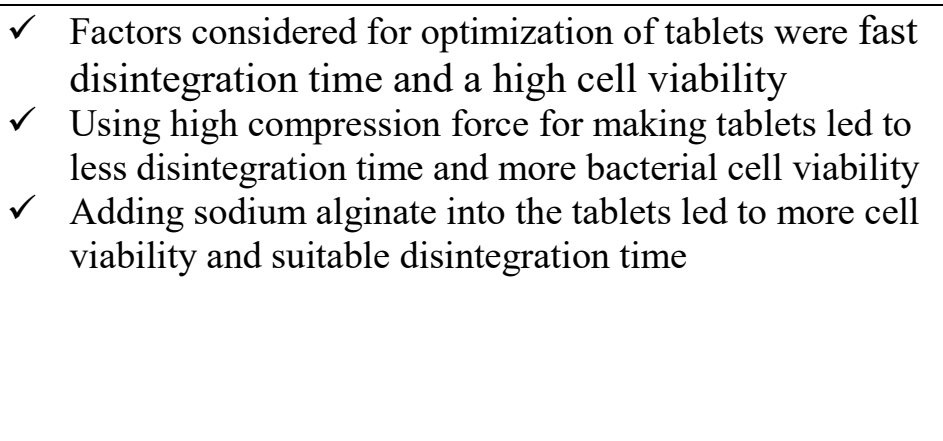 & [158] \\
\hline $\begin{array}{l}\text { Tablets including } \\
\text { HPMCAS } \\
\text { (Hydroxypropylmet } \\
\text { hylcellulose acetate } \\
\text { succinate) and } \\
\text { alginates, apple } \\
\text { pectin and } \\
\text { Metolose }{ }^{\circledR} \text { as } \\
\text { matrix forming } \\
\text { components }\end{array}$ & $\begin{array}{l}\text { Lactobacillus } \\
\text { acidophilus La- } \\
5\end{array}$ & Freeze-dried & Compression method & In vitro & $\begin{array}{l}\checkmark \\
\text { High concentration of HPMCAS and a medium or high } \\
\text { compaction force is necessary to obtain gastric juice } \\
\text { resistance } \\
\checkmark \\
\text { The most protective effect of the tablets within artificial } \\
\text { gastric fluid was resulted by compaction mixtures of } \\
\text { LAB, HPMCAS and sodium alginate }\end{array}$ & [177] \\
\hline $\begin{array}{l}\text { Tablets made from } \\
\text { CM-HAS } \\
\text { (Carboxymethyl } \\
\text { high amylose } \\
\text { starch) }\end{array}$ & $\begin{array}{l}\text { Escherichia coli } \\
\text { (E. coli) }\end{array}$ & Freeze-dried & Compression method & In vitro & 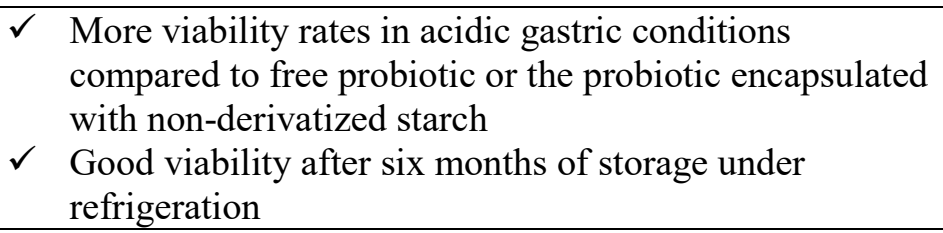 & [161] \\
\hline $\begin{array}{l}\text { Tablets made from } \\
\text { lactoglobulin or } \\
\text { succinylated - } \\
\text { lactoglobulin }\end{array}$ & $\begin{array}{l}\text { Bifidobacterium } \\
\text { longum HA-135 }\end{array}$ & Freeze-dried & Compression method & In vitro & $\begin{array}{l}\text { Succinylated -lactoglobulin showed survivals above } 10^{8} \\
\text { and } 10^{7} \mathrm{CFU} \text { after } 1 \mathrm{~h} \text { and } 2 \mathrm{~h} \text { incubation in acidic } \\
\text { medium. }\end{array}$ & [34] \\
\hline
\end{tabular}




\begin{tabular}{|l|l|l|l|l|}
\hline & & & & $\begin{array}{l}\checkmark \\
\text { Native lactoglobulin did not preserve B. longum within } \\
\text { acidic gastric fluid. } \\
\text { These tablets showed stability during 3 months of } \\
\text { storage under refrigeration }\end{array}$ \\
\hline
\end{tabular}




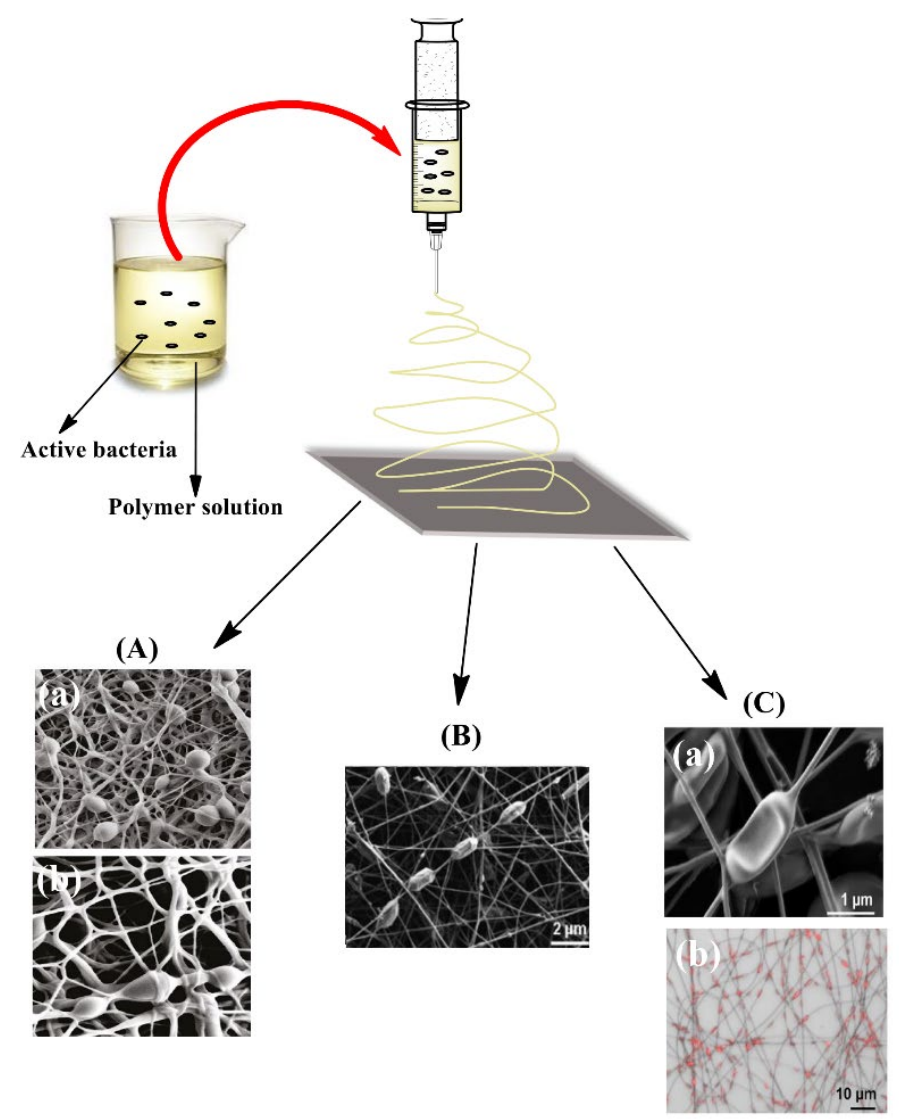

Figure 6. Electrospinning a blend solution of active live bacteria and a polymer to make: (A) active $L$. acidophilus -loaded electrospun nanofibers of (a) okara, and (b) oil palm trunk (OPT) [117]; (B) electrospun PEO nanofibers encapsulated by bacterial strain 25.2M [164]; and (C) PEO electrospun nanofibers loaded by L. plantarum as shown in (a) SEM and (b) confocal microscopy images [123].

\section{8-Possibilities for target delivery of probiotics}

Although most cargoes are released in the upper GI-tract, delivery to the colon is more important for some probiotics. Colon targeted delivery of probiotics would aim for general health or to treat gastrointestinal conditions including ulcerative colitis, Crohn's disease, and colonic cancer $[26,178]$. In general, colon delivery is preferred for some cargoes (including peptides and proteins) which are prone to hydrolysis or enzymatic degradation in duodenum and jejunum. Releasing the cargo into the ileum or colon would lead to higher systemic bioavailability[179] and may enhance 
colonization of probiotics due to longer residence times in colon[66]. For such target deliveries, extra coatings to protect probiotics from degradation in the stomach and small intestine are required. The coatings help to further activation by colon secreted enzymes. Several enzymes such as $\beta$ d-glucosidase, $\beta$-d-galactosidase, $\beta$-xylosidase, $\beta$-arabinosidase, azo-reductase, and nitroreductase are secreted by colonic microflora[63]. These enzymes will degrade the carrier material (the coating) and help to release the probiotics into the colon. A novel technique for colon-targeted delivery is to use enzymatic reduction of azo-linkages in azo-containing polymers by azo-reductase enzymes in colonic microflora [180]. Aromatic azo polymers have shown the potential for colon targeting since reduction and cleavage of the azo bond only occurs in the large intestine, and therefore the delivery is site-specific[180]. The enzymes are secreted in both healthy and diseased colon (inflamed or cancer colon), and the mechanism of the reduction in the inflamed colon is shown in Figure 7.
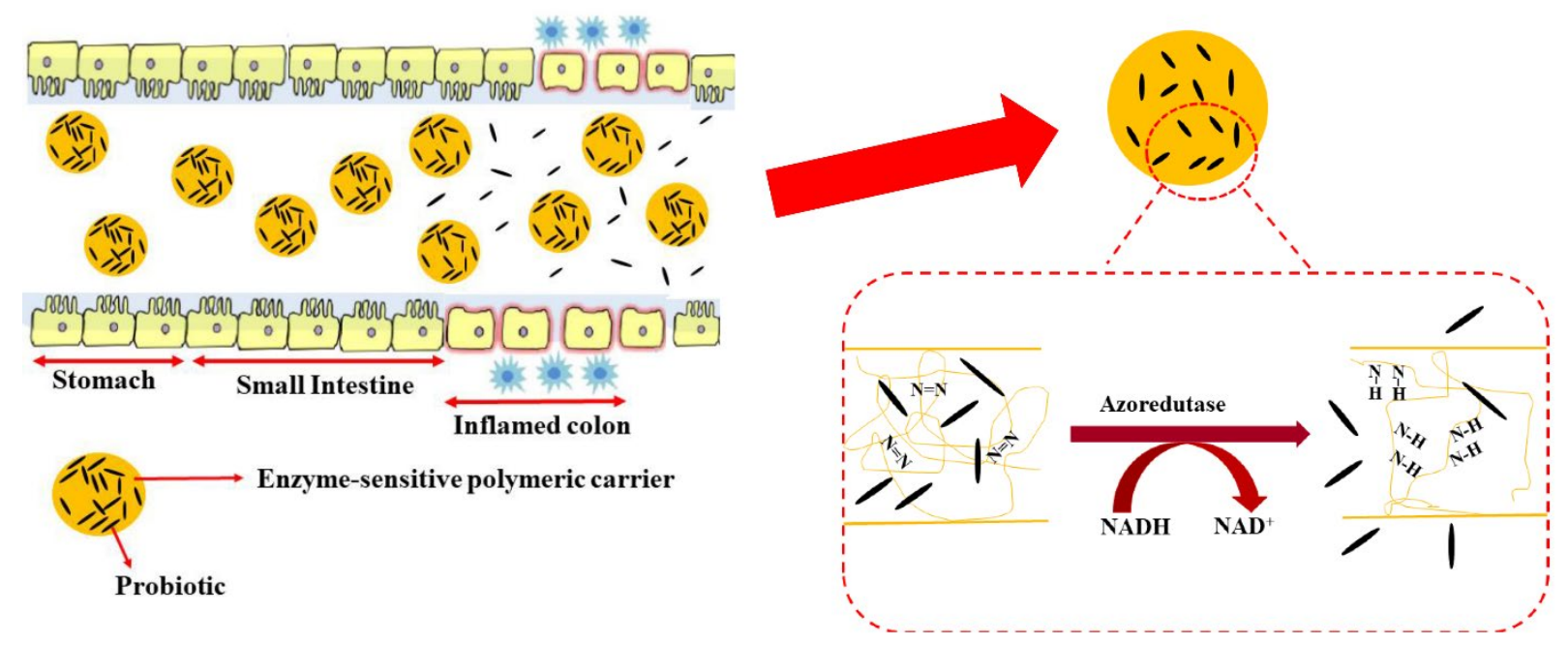

Figure 7. mechanism of reducing azo-linkages by azo-reductase in colon [181, 182]

Azo-reductases are Flavin-free or Flavin-containing group of enzymes that utilize the nicotinamide adenine dinucleotide $(\mathrm{NADH})$ or nicotinamide adenine dinucleotide phosphate (NADPH) as a reducing agent to reduce the azo-linkages[183]. A simple example to describe 
the catalytic role of azoreductase enzyme is using 2 equivalents of $\mathrm{NAD}(\mathrm{P}) \mathrm{H}$ for reducing one equivalent of azo compound $\left(\mathrm{Ar}-\mathrm{N}=\mathrm{N}-\mathrm{Ar}\right.$, where $\mathrm{Ar}=\mathrm{p}$-dimethylaniline and $\mathrm{Ar} \mathrm{r}^{\prime}=\mathrm{o}$-benzoic acid) into two equivalents of aniline [184]. For instance, an azo-polyurethane was synthesized from the reaction of isophorone diisocyanate with a mixture of $\mathrm{m}, \mathrm{m}$-di(hydroxymethyl) azobenzene, polyethylene glycol, and 1, 2-propanediol. The releasing of the entrapped cargo occurred after reduction of the azo group [181, 185]. In another research azo-reductase sensitive polymeric micelles were prepared by covalent binding of polyethylene glycol (PEG) and poly (styrene) (PS) through azobenzene bond [186]. pH-sensitive azopolymeric hydrogels are another type of azo-containing polymers that have azo-crossinkers. In this system, the hydrogel swells in intestinal $\mathrm{pH}$ and exposes the azo-linkages to the azo-reductase in colon. For example, polyanionic hydrogels containing polyacrylic acid and azo-crosslinkers were synthesized for target colon delivery. These hydrogels do not swell in the stomach $\mathrm{pH}$ but swell in the intestine $\mathrm{pH}$. By swelling, the azo-crosslinkers are exposed to the azo-reductase and are degraded by this enzyme[187, 188]. Another method is active targeting to have specific colon delivery. This means that with regard to the specific receptors on normal or diseased colon cells (inflamed or cancer colon cells), the carriers can be modified accordingly. Lectins are an example of carbohydrate binding proteins [189]. Lectins specifically bind to glycolipids or glycoproteins expressed on cell surface membranes of some parts of intestinal mucosa[190]. The interaction between lectins and carbohydrates is specific, and is similar to enzymesubstrate, or antigen-antibody interactions. The most important property of lectins is their specific saccharide-binding sites. In addition, some lectins are expressed on the surface of cell membranes, and can be applied as a target for colon-specific drug delivery. As mentioned above, both lectins and carbohydrates can be overexpressed on the surface of the colon cells. So, two types of lectin targeting the colon known as direct lectin targeting and reverse lectin targeting can be defined (Figure 8A) [191]. An example for reverse lectin targeting, is 
development of colon-targeted delivery systems based on the reverse lectin targeting of N-(2hydroxypropyl) methacrylamide (HPMA) copolymer-conjugated WGA and PNA[48].In this example, WGA is wheat germ agglutinin and PNA is peanut agglutinin that binds to N-acetylD-glucosamine and $\alpha$-lactose as the carbohydrates, respectively[48]. Lectins are classified to plant lectins and animal lectins and each type of these lectins has different specific interactions with carbohydrates. For instance, C-type lectins that are the most commonly used animal lectins can bind with carbohydrates in the presence of $\mathrm{Ca}^{2+}$ ions. Figure $8 \mathrm{~B}$ shows the interactions between C-type animal lectin and mannose as the carbohydrate. The C-type lectin folding is so specific and has a domain with 110-130 amino acid residues with a double-looped and a two-stranded antiparallel $\beta$-sheet. $\mathrm{Ca}^{2+}$ ions that are in the carbohydrate-recognition domains are coordinated to amino acid residues with carbonyl side chains[192]. Such specific target delivery can help for better use of common probiotics in cell therapy, and will hopefully serve for better employment of Next Generation Probiotics[193] (NGP). NGP are more likely to be delivered under a drug regulatory framework to treat different diseases such as diabetes, mellitus, liver diseases, cardiovascular diseases, cancer and neurodegenerative diseases[194]. 
(A)

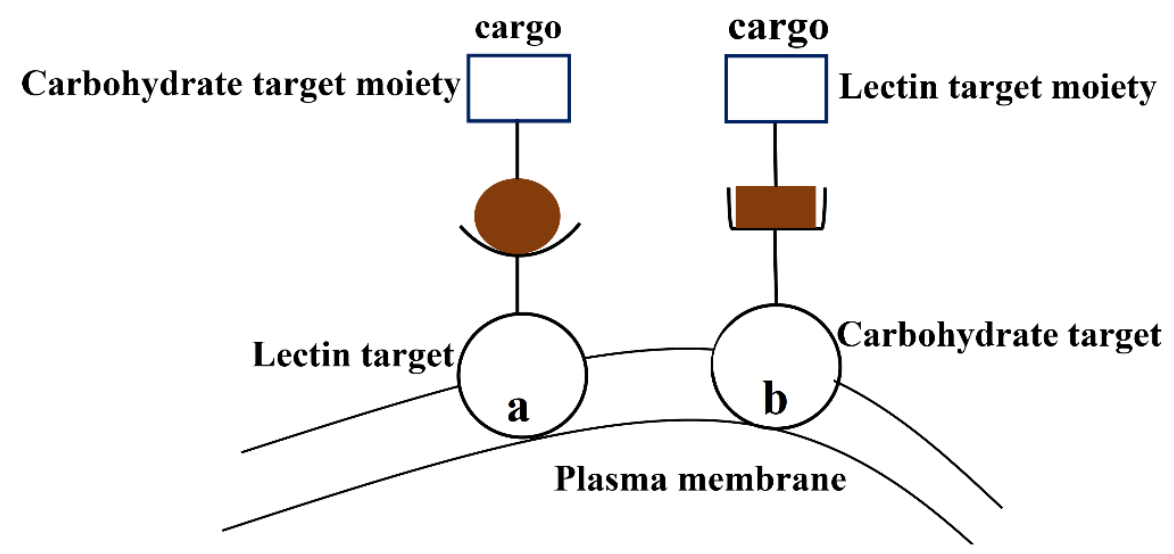

(B)

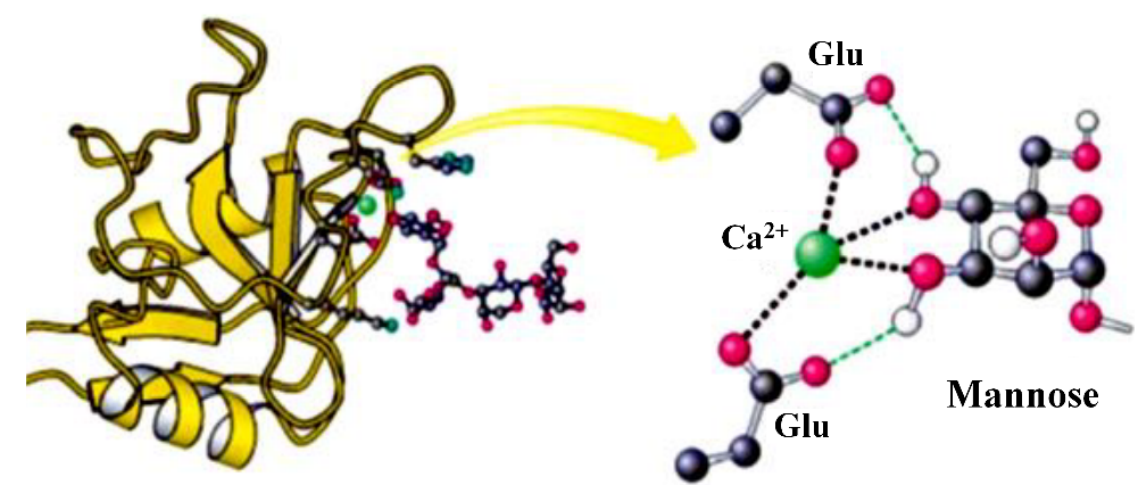

Figure 8. Lectin targeting in two forms of direct (a) and reverse (b) in (A) [191], and schematic representation of the interaction between C-type animal lectin and mannose in the presence of $\mathrm{Ca}^{2+}$ ions (B)[192].

\section{9- Challenges with Use of Probiotics}

While the aim of this study was to focus on use of polymeric carriers for enhanced delivery of probiotics, we want to emphasize the importance of paying attention to the inherent features of the bacterial strain which is intended for delivery[195]. Big individual differences exist between both commercially available and next generation probiotics. Also, the mode-of-action, efficacy, and colonization ability of a given bacterial strain is important to consider along with its potential for withstanding a process of encapsulation.

The use of polymeric carriers for enhanced and targeted delivery of probiotics is currently a hot topic. Application of polymers either for coating of encapsulated probiotics (aiming for 
gastric protection) or as carriers for direct encapsulation of live micro-organisms should be performed by procedures allowing high bacterial survival to lead to optimal final properties. Several studies have emerged assessing the use of polymeric carries for enhanced delivery of probiotics. More attention is recently attracted towards better adhesion to mucus layer of intestine leading to gradual release and site-specific delivery of probiotics[196, 197]. It is well established that the microbiota of the small intestine is different from that of the colon, and also that the mucosal microbiota differs from that in the luminal tract[198]. The intestinal mucus layer is the point of contact with the host for probiotic bacteria as well as for their metabolic product, and as such, is of special interest. Recently, it was elegantly demonstrated that differences in gut mucosal microbial populations may affect colonization as well as effects of probiotic bacteria [195]. This points towards an important role for targeted delivery of probiotic strains directly to the intestinal mucus layer.

As already stated, the formula of commercial probiotics usually includes some polymeric carriers. Such polymeric additives are usually considered as "excipients" and details about their manufacturing procedure or the role of additive polymers in achieving the outcomes are not studied fully [195, 199]. Further evaluations on rationale behind their inclusion and the observed relevant effects would be interesting and helpful for researchers. An example is the commercial probiotic mixture VSL\#3, which has been demonstrated to have effect against inflammatory bowel diseases (IBD) in both animals[200, 201] and humans (for preventing relapses of pouchitis $[202,203]$, a condition of nonspecific inflammatory at the ileal pouch reservoir[204]). This compound (VSL\#3) consists of eight bacterial species including Streptococcus thermophilus, Bifidobacterium breve, B. longum, B. infantis, Lactobacillus acidophilus, L. plantarum, L. paracasei, and L. delbrueckii subsp. Bulgaricus. In additional to a mixture of eight different lactic acid bacteria, VSL3\#, according to the list of ingredients, contains polymeric carriers including hydroxypropyl methylcellulose (HPMC 
vegetarian capsule), cornstarch, and microcrystalline cellulose [198] The success of this compound in several studies might thus be partly related to the right selection of the specific polymeric carriers involved, and the formula applied for manufacturing.

All in all, from a research point of view, more interdisciplinary work involving microbiologists, medical doctors, and biomaterial/chemical engineers is needed to obtain more efficient design of probiotic formulations. This way, it can be ensured that 1) the most specific/effective probiotic strains are selected, 2) the polymeric carriers applied for manufacturing of the product is optimized with regard to the natural characteristics and sensitivity of the selected strain, and 3) the formulation is improved based on in vitro, in vivo, and pre-clinical optimization procedures. Until July 2019, according to the biomedical database Medline, supported by the National Center for Biotechnology Information (U.S. National Library of Medicine), there have been 2182 clinical trials and 359 systematic reviews on probiotics[199]. Amongst more than 2000 clinical trials focusing on use of probiotics, the underlying role of polymeric carriers on efficient delivery of probiotics is not covered that much. We propose that more attention should be paid to the application of polymeric carriers for enhanced or targeted delivery of probiotics. This would open new doors also to clinical use of probiotics.

\section{0-Conclusion}

Probiotics are attracting more and more attention due to their potential as health supplement, but also are a promising option to treat a number of GI and non-GI diseases. The main aim of this review was to elucidate the potential of using polymeric carriers for improving the functionality of probiotics. Polymeric carriers have proved to increase the viability of probiotics during fabrication, storage, and passage through the acidic stomach. Some polymers do also assist with the targeted delivery of probiotics into the colon and/or mucosal environment. We conclude that correct selection of the polymeric carrier(s) with regard to the candidate strain, fabrication procedure, storage conditions and the target site of delivery would 
improve the functionality of probiotics and it is expected to pave the way for more use of probiotics in clinical applications.

\section{References:}

[1] C. Hill, F. Guarner, G. Reid, G.R. Gibson, D.J. Merenstein, B. Pot, L. Morelli, R.B. Canani, H.J. Flint, S. Salminen, Expert consensus document: The International Scientific Association for Probiotics and Prebiotics consensus statement on the scope and appropriate use of the term probiotic, Nat. Rev. Gastroenterol. Hepatol., 11 (2014) 506-514. doi: 10.1038/nrgastro.2014.66.

[2] F. Joint, WHO working group report on drafting guidelines for the evaluation of probiotics in food, London, Ontario, Canada, 30 (2002).

[3] J. Rafter, Probiotics and colon cancer, Best. Pract. Res. Clin. Gastroenterol., 17 (2003) 849-859. doi: 10.1016/s1521-6918(03)00056-8

[4] I. Jankovic, W. Sybesma, P. Phothirath, E. Ananta, A. Mercenier, Application of probiotics in food products - challenges and new approaches, Curr. Opin. Biotechnol., 21 (2010) 175-181. doi: 10.1016/j.copbio.2010.03.009.

[5] S. Prakash, C. Tomaro-Duchesneau, S. Saha, A. Cantor, The gut microbiota and human health with an emphasis on the use of microencapsulated bacterial cells, BioMed. Res. Int., 2011 (2011). doi: $10.1155 / 2011 / 981214$.

[6] C. Guo, J. Li, Hypocholesterolaemic action of Lactobacillus casei F0822 in rats fed a cholesterolenriched diet, Int. Dairy J., 32 (2013) 144-149. https://doi.org/10.1016/j.idairyj.2013.04.001.

[7] Ö. Öner, B. Aslim, S.B. Aydaş, Mechanisms of cholesterol-lowering effects of lactobacilli and bifidobacteria strains as potential probiotics with their bsh gene analysis, J. Mol. Microbiol. Biotechnol., 24 (2014) 12-18. doi: 10.1159/000354316.

[8] R. Ashraf, N.P. Shah, Immune system stimulation by probiotic microorganisms, Crit. rev. food. sci. nutr., 54 (2014) 938-956. https://doi.org/10.1080/10408398.2011.619671.

[9] E.A. Trush, E.A. Poluektova, A.G. Beniashvilli, O.S. Shifrin, Y.M. Poluektov, V.T. Ivashkin, The Evolution of Human Probiotics: Challenges and Prospects, Probiotics. Antimicro. (2020) 1-9. doi: 10.1007/s12602-019-09628-4.

[10] L.-S. Chou, B. Weimer, Isolation and characterization of acid-and bile-tolerant isolates from strains of Lactobacillus acidophilus, J. Dairy Sci., 82 (1999) 23-31. doi: 10.3168/jds.S0022-0302(99)75204-5.

[11] G. Vinderola, A. Binetti, P. Burns, J. Reinheimer, Cell viability and functionality of probiotic bacteria in dairy products, Front. Microbiol., 2 (2011) 70. doi: 10.3389/fmicb.2011.00070.

[12] G. Deshpande, G. Athalye-Jape, S. Patole, Para-probiotics for preterm neonates - the next frontier, Nutrients, 10 (2018) 871. doi: 10.3390/nu10070871.

[13] K. Kato, T. Odamaki, E. Mitsuyama, H. Sugahara, J.-z. Xiao, R. Osawa, Age-related changes in the composition of gut Bifidobacterium species, Curr. microbiol., 74 (2017) 987-995. doi: 10.1007/s00284-017-1272-4.

[14] K.W. Kim, S.-S. Kang, S.-J. Woo, O.-J. Park, K.B. Ahn, K.-D. Song, H.-K. Lee, C.-H. Yun, S.H. Han, Lipoteichoic acid of probiotic Lactobacillus plantarum attenuates poly I: C-induced IL-8 production in porcine intestinal epithelial cells, Front. microbiol., 8 (2017) 1827. doi: 10.3389/fmicb.2017.01827.

[15] E.J. Goldstein, K.L. Tyrrell, D.M. Citron, Lactobacillus species: taxonomic complexity and controversial susceptibilities, Clin. Infect. Dis., 60 (2015) S98-S107. doi: 10.1093/cid/civ072.

[16] A.Y. Tamime, V.M. Marshall, R.K. Robinson, Microbiological and technological aspects of milks fermented by bifidobacteria, $J D R$, 62 (1995) 151-187. doi: 10.1017/s002202990003377x.

[17] G.V. Zuccotti, F. Meneghin, C. Raimondi, D. Dilillo, C. Agostoni, E. Riva, M. Giovannini, Probiotics in clinical practice: an overview, J. Int. Med. Res., 36 (2008) 1A-53A. doi: $10.1177 / 14732300080360$ S101. 
[18] V. De Preter, H.M. Hamer, K. Windey, K. Verbeke, The impact of pre-and/or probiotics on human colonic metabolism: Does it affect human health?, Mol. Nutr. Food. Res., 55 (2011) 46-57. doi: 10.1002/mnfr.201000451

[19] M. Kumar, A. Kumar, R. Nagpal, D. Mohania, P. Behare, V. Verma, P. Kumar, D. Poddar, P. Aggarwal, C. Henry, Cancer-preventing attributes of probiotics: an update, Int. J. Food. Sci. Nutr., 61 (2010) 473-496. doi: 10.3109/09637480903455971.

[20] J. Rafter, The effects of probiotics on colon cancer development, Nutr. Res. Rev., 17 (2004) $277-$ 284. doi: $10.1079 /$ NRR200484.

[21] S.J. Allen, B. Okoko, E.G. Martinez, G.V. Gregorio, L.F. Dans, Probiotics for treating infectious diarrhoea, Cochrane Database. Syst. Rev. , 2, (2004). doi: 10.1002/14651858.CD003048.pub2.

[22] E. Ahmadi, M.S. Rezai, The prophylactic effect of Lactobacillus rhamnosus GG on incidence of acute rotavirus diarrhea in children: a systematic review randomized double-blind placebo-controlled trials, J. Pediatr. Rev., 2 (2014) 12-20. http://jpr.mazums.ac.ir/article-1-85-fa.html.

[23] A. Armuzzi, F. Cremonini, V. Ojetti, F. Bartolozzi, F. Canducci, M. Candelli, L. Santarelli, G. Cammarota, A. De Lorenzo, P. Pola, Effect of Lactobacillus GG supplementation on antibioticassociated gastrointestinal side effects during Helicobacter pylori eradication therapy: a pilot study, Digestion, 63 (2001) 1-7. doi: 10.1159/000051865.

[24] M.-T. Liong, Roles of probiotics and prebiotics in colon cancer prevention: postulated mechanisms and in-vivo evidence, Int. J. Mol. Sci., 9 (2008) 854-863. doi: 10.3390/ijms9050854.

[25] V.G. Yadav, A probiotic for treating cancer, Sci. Transl. Med., 11 (2019) eaay3576. doi: 10.1126/scitranslmed.aay3576.

[26] L. He, H. Yang, J. Tang, Z. Liu, Y. Chen, B. Lu, H. He, S. Tang, Y. Sun, F. Liu, Intestinal probiotics E. coli Nissle 1917 as a targeted vehicle for delivery of p53 and Tum-5 to solid tumors for cancer therapy, J. Biol. Eng., 13 (2019) 58. doi: 10.1186/s13036-019-0189-9.

[27] R. Nagpal, A. Kumar, M. Kumar, P.V. Behare, S. Jain, H. Yadav, Probiotics, their health benefits and applications for developing healthier foods: a review, FEMS Microbiol. lett., 334 (2012) 1-15. doi: 10.1111/j.1574-6968.2012.02593.x.

[28] M.K. Tripathi, S.K. Giri, Probiotic functional foods: Survival of probiotics during processing and storage, J. Funct. Foods, 9 (2014) 225-241. https://doi.org/10.1016/j.jff.2014.04.030.

[29] S. Vesterlund, K. Salminen, S. Salminen, Water activity in dry foods containing live probiotic bacteria should be carefully considered: A case study with Lactobacillus rhamnosus GG in flaxseed, Int. J. Food Microbiol., 157 (2012) 319-321. doi: 10.1016/j.ijfoodmicro.2012.05.016.

[30] M.T. Cook, G. Tzortzis, D. Charalampopoulos, V.V. Khutoryanskiy, Microencapsulation of probiotics for gastrointestinal delivery, J. Controlled Release, 162 (2012) 56-67. doi: 10.1016/j.jconrel.2012.06.003.

[31] J. Schrezenmeir, M. de Vrese, Probiotics, prebiotics, and synbiotics-approaching a definition, Am. J.Clin. Nutr., 73 (2001) 361 s-364s. doi: 10.1093/ajen/73.2.361s.

[32] M. Kechagia, D. Basoulis, S. Konstantopoulou, D. Dimitriadi, K. Gyftopoulou, N. Skarmoutsou, E.M. Fakiri, Health benefits of probiotics: a review, ISRN Nutr., 2013 (2013) 481651. doi: $10.5402 / 2013 / 481651$.

[33] C.C. Dodoo, J. Wang, A.W. Basit, P. Stapleton, S. Gaisford, Targeted delivery of probiotics to enhance gastrointestinal stability and intestinal colonisation, Int. J. Pharm., 530 (2017) 224-229. doi: 10.1016/j.ijpharm.2017.07.068.

[34] J.-F. Poulin, R. Caillard, M. Subirade, $\beta$-Lactoglobulin tablets as a suitable vehicle for protection and intestinal delivery of probiotic bacteria, Int. J. Pharm., 405 (2011) 47-54. doi: 10.1016/j.ijpharm.2010.11.041.

[35] E. Rouèche, E. Serris, G. Thomas, L. Périer-Camby, Influence of temperature on the compaction of an organic powder and the mechanical strength of tablets, Powder Technol., 162 (2006) 138-144. https://doi.org/10.1016/j.powtec.2005.12.005.

[36] W. Krasaekoopt, B. Bhandari, H. Deeth, The influence of coating materials on some properties of alginate beads and survivability of microencapsulated probiotic bacteria, Int. Dairy J., 14 (2004) 737743. https://doi.org/10.1016/j.idairyj.2004.01.004. 
[37] S. Chen, Q. Zhao, L.R. Ferguson, Q. Shu, I. Weir, S. Garg, Development of a novel probiotic delivery system based on microencapsulation with protectants, Appl. Microbiol. Biotechnol., 93 (2012) 1447-1457. doi: 10.1007/s00253-011-3609-4.

[38] M.T. Cook, G. Tzortzis, D. Charalampopoulos, V.V. Khutoryanskiy, Production and evaluation of dry alginate-chitosan microcapsules as an enteric delivery vehicle for probiotic bacteria, Biomacromolecules, 12 (2011) 2834-2840. doi: 10.1021/bm200576h.

[39] K. Fijałkowski, D. Peitler, R. Rakoczy, A. Żywicka, Survival of probiotic lactic acid bacteria immobilized in different forms of bacterial cellulose in simulated gastric juices and bile salt solution, LWT-Food Sci. Technol., 68 (2016) 322-328. doi: 10.1016/j.lwt.2015.12.038.

[40] A. Jagannath, P. Raju, A. Bawa, Comparative evaluation of bacterial cellulose (nata) as a cryoprotectant and carrier support during the freeze drying process of probiotic lactic acid bacteria, LWT-Food Sci. Technol., 43 (2010) 1197-1203. doi: 10.1016/j.lwt.2010.03.009.

[41] J.M. Lakkis, Encapsulation and controlled release technologies in food systems, Wiley Online Library 2007.

[42] N.J. Zuidam, V. Nedovic, Encapsulation technologies for active food ingredients and food processing, (2010).

[43] M.R.I. Shishir, L. Xie, C. Sun, X. Zheng, W. Chen, Advances in micro and nano-encapsulation of bioactive compounds using biopolymer and lipid-based transporters, Trends Food Sci. Technol., 78 (2018) 34-60. https://doi.org/10.1016/j.tifs.2018.05.018.

[44] M.A. Augustin, L. Sanguansri, Encapsulation Methods physical processes, short course on microand nano-encapsulation of functional ingredients in food products, world congress on oils and fats \& fats and 31 th lectureship series.

[45] R. Ji, J. Wu, J. Zhang, T. Wang, X. Zhang, L. Shao, D. Chen, J. Wang, Extending Viability of Bifidobacterium longum in Chitosan-Coated Alginate Microcapsules Using Emulsification and Internal Gelation Encapsulation Technology, Front. Microbiol., $10 \quad$ (2019) 1389. https://doi.org/10.3389/fmicb.2019.01389.

[46] A. Sun, M. Goosen, G. O'shea, Microencapsulated cells as hormone delivery systems, Crit. Rev. Ther. Drug Carrier Syst., 4 (1987) 1-12.

[47] B. Ríhová, Immunocompatibility and biocompatibility of cell delivery systems, Adv. Drug Del. Rev., 42 (2000) 65-80. doi: 10.1016/s0169-409x(00)00054-5.

[48] T.M.S. Chang, S. Prakash, Therapeutic uses of microencapsulated genetically engineered cells, Mol. Med. Today, 4 (1998) 221-227. doi: 10.1016/s1357-4310(98)01246-5.

[49] A. López-Rubio, E. Sanchez, S. Wilkanowicz, Y. Sanz, J.M. Lagaron, Electrospinning as a useful technique for the encapsulation of living bifidobacteria in food hydrocolloids, Food Hydrocoll., 28 (2012) 159-167.doi: 10.1016/j.foodhyd.2011.12.008.

[50] M. Sharp, D.J. McMahon, J.R. Broadbent, Comparative evaluation of yogurt and low-fat cheddar cheese as delivery media for probiotic Lactobacillus casei, J. Food Sci., 73 (2008) M375-M377. doi: 10.1111/j.1750-3841.2008.00882.x.

[51] A. Homayouni, A. Azizi, M. Ehsani, M. Yarmand, S. Razavi, Effect of microencapsulation and resistant starch on the probiotic survival and sensory properties of synbiotic ice cream, Food chem., 111 (2008) 50-55. doi: 10.1016/j.foodchem.2008.03.036.

[52] V. Manojlović, V.A. Nedović, K. Kailasapathy, N.J. Zuidam, Encapsulation of probiotics for use in food products, Encapsulation technologies for active food ingredients and food processing, Springer2010, pp. 269-302.

[53] R.L. Kronenthal, Biodegradable polymers in medicine and surgery, Polymers in medicine and surgery, Springer1975, pp. 119-137.

[54] S. Neha, S. Harikumar, Polymers for Colon Targeted Drug Delivery: A Review, Int. J. Drug. Dev. Res., 5 (2013) 21-23.

[55] A. Tiwari, A. Verma, P.K. Panda, S. Saraf, A. Jain, S.K. Jain, Stimuli-responsive polysaccharides for colon-targeted drug delivery, Stimuli Responsive Polymeric Nanocarriers for Drug Delivery Applications, Elsevier2019, pp. 547-566.

[56] V.R. Sinha, R. Kumria, Polysaccharides in colon-specific drug delivery, Int. J. Pharm., 224 (2001) 19-38. doi: 10.1016/s0378-5173(01)00720-7. 
[57] H. Rajpurohit, P. Sharma, S. Sharma, A. Bhandari, Polymers for colon targeted drug delivery, Indian J. Pharm. Sci., 72 (2010) 689. doi: 10.4103/0250-474X.84576.

[58] M. Chávarri, I. Marañón, R. Ares, F.C. Ibáñez, F. Marzo, M. del Carmen Villarán, Microencapsulation of a probiotic and prebiotic in alginate-chitosan capsules improves survival in simulated gastro-intestinal conditions, Int. J. Food Microbiol., 142 (2010) 185-189. doi: 10.1016/j.ijfoodmicro.2010.06.022.

[59] C. Wandrey, A. Bartkowiak, S.E. Harding, Materials for encapsulation, Encapsulation technologies for active food ingredients and food processing, Springer2010, pp. 31-100.

[60] C.Y. Falco, P. Falkman, J. Risbo, M. Cárdenas, B. Medronho, Chitosan-dextran sulfate hydrogels as a potential carrier for probiotics, Carbohydr. Polym., 172 (2017) 175-183. doi: 10.1016/j.carbpol.2017.04.047.

[61] P. Hari, T. Chandy, C.P. Sharma, Chitosan/calcium-alginate beads for oral delivery of insulin, J. Appl. Polym. Sci., $59 \quad$ (1996) $\quad 1795-1801 . \quad$ https://doi.org/10.1002/(SICI)10974628(19960314)59:11<1795::AID-APP16>3.0.CO;2-T.

[62] M.A. Islam, C.-H. Yun, Y.-J. Choi, C.-S. Cho, Microencapsulation of live probiotic bacteria, J. Microbiol. Biotechnol., 20 (2010) 1367-1377. doi: 10.4014/jmb.1003.03020.

[63] R.R. Scheline, Metabolism of foreign compounds by gastrointestinal microorganisms, Pharmacol. Rev., 25 (1973) 451-523.

[64] L.F.A. Asghar, S. Chandran, Multiparticulate formulation approach to colon specific drug delivery: current perspectives, J. Pharm. Pharm. Sci., 9 (2006) 327-338.

[65] L. Yang, J.S. Chu, J.A. Fix, Colon-specific drug delivery: new approaches and in vitro/in vivo evaluation, Int. J. Pharm., 235 (2002) 1-15. https://doi.org/10.1016/S0378-5173(02)00004-2.

[66] A.K. Philip, B. Philip, Colon targeted drug delivery systems: a review on primary and novel approaches, Oman Med. J., 25 (2010) 79-87. doi: 10.5001/omj.2010.24.

[67] M. Saffran, C. Bedra, G.S. Kumar, D.C. Neckers, Vasopressin: a model for the study of effects of additives on the oral and rectal administration of peptide drugs, J. Pharm. Sci., 77 (1988) 33-38. https://doi.org/10.1002/jps.2600770107.

[68] M. Saffran, G.S. Kumar, C. Savariar, J.C. Burnham, F. Williams, D.C. Neckers, A new approach to the oral administration of insulin and other peptide drugs, Sci, 233 (1986) 1081-1084. doi: 10.1126/science.3526553.

[69] V.K. Nikam, K. Kotade, V. Gaware, R. Dolas, K. Dhamak, S. Somwanshi, A. Khadse, V. Kashid, Eudragit a versatile polymer: a review, Pharmacologyonline, 1 (2011) 152-164.

[70] Z. Dong, Q. Wang, Y. Du, Alginate/gelatin blend films and their properties for drug controlled release, J. Membr. Sci., 280 (2006) 37-44. https://doi.org/10.1016/j.memsci.2006.01.002.

[71] S. Thomas, Alginate dressings in surgery and wound management-Part 1, J. wound care, 9 (2000) 56-60. doi: 10.12968/jowc.2000.9.2.26338.

[72] N.E. Simpson, C.L. Stabler, C.P. Simpson, A. Sambanis, I. Constantinidis, The role of the $\mathrm{CaCl}_{2}-$ guluronic acid interaction on alginate encapsulated $\beta$ TC3 cells, Biomaterials, 25 (2004) 2603-2610. doi: 10.1016/j.biomaterials.2003.09.046.

[73] Z.-P. Xie, Y. Huang, Y.-L. Chen, Y. Jia, A new gel casting of ceramics by reaction of sodium alginate and calcium iodate at increased temperatures, J. Mater. Sci. Lett., 20 (2001) 1255-1257. doi: 10.1023/A:1010943427450

[74] S. Verma, V. Kumar, D. Mishra, S. Singh, Colon targeted drug delivery: current and novel perspectives, Int. J. Pharm. Sci. . Res., 3 (2012) 1274-1284.

[75] T.S. Anirudhan, J. Christa, Multi-polysaccharide based stimuli responsive polymeric network for the in vitro release of 5-fluorouracil and levamisole hydrochloride, New J. Chem., 41 (2017) 1197911990. https://doi.org/10.1039/C7NJ01745F.

[76] S.H. Lee, R. Bajracharya, J.Y. Min, J.-W. Han, B.J. Park, H.-K. Han, Strategic Approaches for Colon Targeted Drug Delivery: An Overview of Recent Advancements, Pharmaceutics, 12 (2020) 68. doi: 10.3390/pharmaceutics12010068.

[77] J. Kim, N. Muhammad, B.H. Jhun, J.-W. Yoo, Probiotic delivery systems: a brief overview, $J$. Pharm. Investig., 46 (2016) 377-386. doi: 10.1007/s40005-016-0259-7.

[78] D. de Almeida Paula, E.M.F. Martins, N. de Almeida Costa, P.M. de Oliveira, E.B. de Oliveira, A.M. Ramos, Use of gelatin and gum arabic for microencapsulation of probiotic cells from 
Lactobacillus plantarum by a dual process combining double emulsification followed by complex coacervation, Int. J. Biol. Macromol., 133 (2019) 722-731. doi: 10.1016/j.ijbiomac.2019.04.110.

[79] K. Yoda, X. Sun, M. Kawase, A. Kubota, K. Miyazawa, G. Harata, M. Hosoda, M. Hiramatsu, F. He, M.B. Zemel, A combination of probiotics and whey proteins enhances anti-obesity effects of calcium and dairy products during nutritional energy restriction in aP2-agouti transgenic mice, $B r . J$. Nutr., 113 (2015) 1689-1696. doi: 10.1017/S0007114515000914.

[80] T. Heidebach, P. Först, U. Kulozik, Transglutaminase-induced caseinate gelation for the microencapsulation of probiotic cells, Int. Dairy J., 19 (2009) 77-84. doi: 10.1016/j.idairyj.2008.08.003.

[81]R.A. Parra Huertas, Revisión: microencapsulación de alimentos, Rev. Fac. Nac. Agron. Medellin., 63 (2010); 5669-5684.

[82] J. Burgain, C. Gaiani, M. Linder, J. Scher, Encapsulation of probiotic living cells: From laboratory scale to industrial applications, J. food Eng., 104 (2011) 467-483. https://doi.org/10.1016/j.jfoodeng.2010.12.031.

[83] M. Chávarri, I. Marañón, M.C. Villarán, Encapsulation technology to protect probiotic bacteria, Probiotics, IntechOpen2012.

[84] D. Kavitake, S. Kandasamy, P.B. Devi, P.H. Shetty, Recent developments on encapsulation of lactic acid bacteria as potential starter culture in fermented foods-A review, Food Biosci., 21 (2018) 34-44. doi: 10.1016/j.fbio.2017.11.003.

[85] G.K. Gbassi, T. Vandamme, Probiotic encapsulation technology: from microencapsulation to release into the gut, Pharmaceutics, 4 (2012) 149-163. doi: 10.3390/pharmaceutics4010149.

[86] M. Fathi, A. Martin, D.J. McClements, Nanoencapsulation of food ingredients using carbohydrate based delivery systems, Trends Food Sci. Technol., $39 \quad$ (2014) 18-39. https://doi.org/10.1016/j.tifs.2014.06.007.

[87] H. Hayashi, Drying technologies of foods-their history and future, Drying Technol., 7 (1989) 315 369. https://doi.org/10.1080/07373938908916590.

[88] K.G.H. Desai, H. Jin Park, Recent developments in microencapsulation of food ingredients, Drying Technol., 23 (2005) 1361-1394. https://doi.org/10.1081/DRT-200063478.

[89] S. Rokka, P. Rantamäki, Protecting probiotic bacteria by microencapsulation: challenges for industrial applications, Eur. Food. Res. Technol., 231 (2010) 1-12. doi: 10.1007/s00217-010-1246-2.

[90] E. Goldberg, Handbook of downstream processing, Springer Science \& Business Media2012.

[91] G.-W. Oetjen, P. Haseley, Freeze-drying, John Wiley \& Sons2004.

[92] T. Heidebach, P. Först, U. Kulozik, Influence of casein-based microencapsulation on freeze-drying and storage of probiotic cells, J. Food Eng., 98 (2010) 309-316. doi: 10.1016/j.jfoodeng.2010.01.003.

[93] G. Nireesha, L. Divya, C. Sowmya, N. Venkateshan, M.N. Babu, V. Lavakumar, Lyophilization/freeze drying-an review, IJNTPS, 3 (2013) 87-98.

[94] D. Semyonov, O. Ramon, Z. Kaplun, L. Levin-Brener, N. Gurevich, E. Shimoni, Microencapsulation of Lactobacillus paracasei by spray freeze drying, Food Res. Int., 43 (2010) 193202. https://doi.org/10.1016/j.foodres.2009.09.028.

[95] N.J. Zuidam, V. Nedović, Encapsulation technologies for active food ingredients and food processing, (2010).

[96] C. Anandharamakrishnan, C.D. Rielly, A.G. Stapley, Spray-freeze-drying of whey proteins at subatmospheric pressures, Dairy Sci. Technol., 90 (2010) 321-334.

[97] P. Ezhilarasi, D. Indrani, B. Jena, C. Anandharamakrishnan, Freeze drying technique for microencapsulation of Garcinia fruit extract and its effect on bread quality, J. Food Eng., 117 (2013) 513-520. https://doi.org/10.1016/j.jfoodeng.2013.01.009.

[98] P. Dolly, A. Anishaparvin, G. Joseph, C. Anandharamakrishnan, Microencapsulation of Lactobacillus plantarum (mtcc 5422) by spray-freeze-drying method and evaluation of survival in simulated gastrointestinal conditions, J. Microencaps., 28 (2011) 568-574. $\quad$ doi: 10.3109/02652048.2011.599435.

[99] .M. Rutherford, J.E. Allen, H.W. Schlameus, D.J. Mangold, W.W. Harlowe Jr, J.R. Lebeda, Process for preparing rotary disc fatty acid microspheres of microorganisms, Google Patents, 1994.

[100] D. Eratte, S. McKnight, T.R. Gengenbach, K. Dowling, C.J. Barrow, B.P. Adhikari, Coencapsulation and characterisation of omega-3 fatty acids and probiotic bacteria in whey protein 
isolate-gum Arabic complex coacervates, J. Funct. Foods, 19 (2015) 882-892. https://doi.org/10.1016/j.jff.2015.01.037.

[101] L. Kearney, M. Upton, A. Mc Loughlin, Enhancing the viability of Lactobacillus plantarum inoculum by immobilizing the cells in calcium-alginate beads incorporating cryoprotectants, Appl. Environ. Microbiol., 56 (1990) 3112-3116. 0099-2240/90/103112-05\$02.00/0.

[102] S. Gouin, Microencapsulation: industrial appraisal of existing technologies and trends, Trends Food Sci. Technol., 15 (2004) 330-347. https://doi.org/10.1016/j.tifs.2003.10.005.

[103] M. Shima, Y. Morita, M. Yamashita, S. Adachi, Protection of Lactobacillus acidophilus from the low $\mathrm{pH}$ of a model gastric juice by incorporation in a W/O/W emulsion, Food Hydrocoll., 20 (2006) 1164-1169. doi: 10.1016/j.foodhyd.2006.01.001.

[104] K. Sultana, G. Godward, N. Reynolds, R. Arumugaswamy, P. Peiris, K. Kailasapathy, Encapsulation of probiotic bacteria with alginate-starch and evaluation of survival in simulated gastrointestinal conditions and in yoghurt, Int. J. Food Microbiol., 62 (2000) 47-55. doi: 10.1016/s01681605(00)00380-9.

[105] F.T. Gentile, E.J. Doherty, D.H. Rein, M.S. Shoichet, S.R. Winn, Polymer science for macroencapsulation of cells for central nervous system transplantation, Reactive Polym., 25 (1995) 207-227.

[106] W. Krasaekoopt, B. Bhandari, H. Deeth, Evaluation of encapsulation techniques of probiotics for yoghurt, Int. Dairy J., 13 (2003) 3-13. https://doi.org/10.1016/S0958-6946(02)00155-3.

[107] S. Mandal, A. Puniya, K. Singh, Effect of alginate concentrations on survival of microencapsulated Lactobacillus casei NCDC-298, Int. Dairy J., 16 (2006) 1190-1195. https://doi.org/10.1016/j.idairyj.2005.10.005.

[108] W.-H. Wu, W.S. Roe, V.G. Gimino, V. Seriburi, D.E. Martin, S.E. Knapp, Low melt encapsulation with high laurate canola oil, Google Patents, 2000.

[109] E.S. Chan, Z. Zhang, Bioencapsulation by compression coating of probiotic bacteria for their protection in an acidic medium, Process Biochem., 40 (2005) 3346-3351. https://doi.org/10.1016/j.procbio.2005.03.001.

[110] B. Ghorani, N. Tucker, Fundamentals of electrospinning as a novel delivery vehicle for bioactive compounds in food nanotechnology, Food Hydrocoll., 51 (2015) 227-240. doi: 10.1016/j.foodhyd.2015.05.024.

[111] A. Bhushani, C. Anandharamakrishnan, Electrospinning and electrospraying techniques: Potential food based applications, Trends Food Sci. Technol., 38 (2014) 21-33. doi: 10.1016/j.tifs.2014.03.004.

[112] M. Noruzi, Electrospun nanofibres in agriculture and the food industry: a review, J. Sci. Food Agric., 96 (2016) 4663-4678. doi: 10.1002/jsfa. 7737.

[113] P. Wen, M.-H. Zong, R.J. Linhardt, K. Feng, H. Wu, Electrospinning: A novel nanoencapsulation approach for bioactive compounds, Trends Food Sci. Technol., 70 (2017) 56-68. https://doi.org/10.1016/j.tifs.2017.10.009.

[114] C.M. Librán, S. Castro, J.M. Lagaron, Encapsulation by electrospray coating atomization of probiotic strains, Innov. Food Sci. Emerg. Technol., 39 (2017) 216-222. https://doi.org/10.1016/j.ifset.2016.12.013.

[115] M.I. Dias, I.C. Ferreira, M.F. Barreiro, Microencapsulation of bioactives for food applications, Food Funct., 6 (2015) 1035-1052. https://doi.org/10.1039/C4FO01175A.

[116] A. López-Rubio, E. Sanchez, Y. Sanz, J.M. Lagaron, Encapsulation of living bifidobacteria in ultrathin PVOH electrospun fibers, Biomacromolecules, 10 (2009) 2823-2829. doi: 10.1021/bm900660b.

[117] W.-Y. Fung, K.-H. Yuen, M.-T. Liong, Agrowaste-based nanofibers as a probiotic encapsulant: fabrication and characterization, J. Agric. Food Chemistry., 59 (2011) 8140-8147. https://doi.org/10.1021/jf2009342.

[118] T. Amna, M.S. Hassan, D.R. Pandeya, M.-S. Khil, I. Hwang, Classy non-wovens based on animate L. gasseri-inanimate poly (vinyl alcohol): upstream application in food engineering, Appl. Microbiol. Biotechnol., 97 (2013) 4523-4531. doi: 10.1007/s00253-012-4666-z. 
[119] A. Lancuški, A.A. Ammar, R. Avrahami, R. Vilensky, G. Vasilyev, E. Zussman, Design of starch-formate compound fibers as encapsulation platform for biotherapeutics, Carbohydr. Polym., 158 (2017) 68-76. doi: 10.1016/j.carbpol.2016.12.003.

[120] M. Nieuwland, P. Geerdink, P. Brier, P. Van Den Eijnden, J.T. Henket, M.L. Langelaan, N. Stroeks, H.C. van Deventer, A.H. Martin, Food-grade electrospinning of proteins, Innov. Food Sci. Emerg. Technol., 20 (2013) 269-275. https://doi.org/10.1016/j.ifset.2013.09.004.

[121] K.N. Chen, M.J. Chen, J.R. Liu, C.W. Lin, H.Y. Chiu, Optimization of incorporated prebiotics as coating materials for probiotic microencapsulation, J. Food Sci., 70 (2005) M260-M266. https://doi.org/10.1111/j.1365-2621.2005.tb09981.x.

[122] R. Rajam, C. Anandharamakrishnan, Spray freeze drying method for microencapsulation of Lactobacillus plantarum, J. Food Eng., $166 \quad$ (2015) 95-103. https://doi.org/10.1016/j.jfoodeng.2015.05.029.

[123] K. Škrlec, Š. Zupančič, S.P. Mihevc, P. Kocbek, J. Kristl, A. Berlec, Development of electrospun nanofibers that enable high loading and long-term viability of probiotics, Eur. J. Pharm. Biopharm., 136 (2019) 108-119. https://doi.org/10.1016/j.ejpb.2019.01.013.

[124] B.J. Kim, T. Park, H.C. Moon, S.Y. Park, D. Hong, E.H. Ko, J.Y. Kim, J.W. Hong, S.W. Han, Y.G. Kim, Cytoprotective alginate/polydopamine core/shell microcapsules in microbial encapsulation, Angew. Chem. Int. Ed., 53 (2014) 14443-14446. https://doi.org/10.1002/anie.201408454.

[125] L.-F. Călinoiu, B.E. Ştefănescu, I.D. Pop, L. Muntean, D.C. Vodnar, Chitosan coating applications in probiotic microencapsulation, Coatings, 9 (2019) 194. https://doi.org/10.3390/coatings9030194.

[126] M. Huguet, R. Neufeld, E. Dellacherie, Calcium-alginate beads coated with polycationic polymers: comparison of chitosan and DEAE-dextran, Process Biochem., 31 (1996) 347-353.

[127] S. Nualkaekul, D. Lenton, M.T. Cook, V.V. Khutoryanskiy, D. Charalampopoulos, Chitosan coated alginate beads for the survival of microencapsulated Lactobacillus plantarum in pomegranate juice, Carbohydr. Polym., 90 (2012) 1281-1287. doi: 10.1016/j.carbpol.2012.06.073.

[128] M.T. Cook, G. Tzortzis, V.V. Khutoryanskiy, D. Charalampopoulos, Layer-by-layer coating of alginate matrices with chitosan-alginate for the improved survival and targeted delivery of probiotic bacteria after oral administration, J. Mater. Chem. B, 1 (2013) 52-60. https://doi.org/10.1039/C2TB00126H.

[129] A.M. Urbanska, J. Bhathena, S. Prakash, Live encapsulated Lactobacillus acidophilus cells in yogurt for therapeutic oral delivery: preparation and in vitro analysis of alginate-chitosan microcapsules, Can. J. Physiol. Pharm., 85 (2007) 884-893. doi: 10.1139/Y07-057.

[130] J.-H. Cui, J.-S. Goh, P.-H. Kim, S.-H. Choi, B.-J. Lee, Survival and stability of bifidobacteria loaded in alginate poly-l-lysine microparticles, Int. J. Pharm., 210 (2000) 51-59. https://doi.org/10.1016/S0378-5173(00)00560-3.

[131] J.-H. Cui, Q.-R. Cao, B.-J. Lee, Enhanced delivery of bifidobacteria and fecal changes after multiple oral administrations of bifidobacteria-loaded alginate poly-l-lysine microparticles in human volunteers, Drug Deliv., 14 (2007) 265-271. https://doi.org/10.1080/10717540601067844.

[132] C. Martoni, J. Bhathena, M.L. Jones, A.M. Urbanska, H. Chen, S. Prakash, Investigation of microencapsulated BSH active Lactobacillus in the simulated human GI tract, BioMed Res. Int., 2007 (2007). https://doi.org/10.1155/2007/13684.

[133] A.M. Urbanska, J. Bhathena, C. Martoni, S. Prakash, Estimation of the potential antitumor activity of microencapsulated Lactobacillus acidophilus yogurt formulation in the attenuation of tumorigenesis in Apc (Min/+) mice, Digest. Dis. Sci., 54 (2009) 264-273. doi: 10.1007/s10620-008$0363-2$.

[134] G. King, A. Daugulis, P. Faulkner, M. Goosen, Alginate-polylysine microcapsules of controlled membrane molecular weight cutoff for mammalian cell culture engineering, Biotechnol. Prog., 3 (1987) 231-240. https://doi.org/10.1002/btpr.5420030407.

[135] A. King, S. Sandler, A. Andersson, The effect of host factors and capsule composition on the cellular overgrowth on implanted alginate capsules, J. Biomed. Mater. Res., 57 (2001) 374-383. https://doi.org/10.1002/1097-4636(20011205)57:3<374::AID-JBM1180>3.0.CO;2-L. 
[136] W. Ouyang, H. Chen, M.L. Jones, T. Metz, T. Haque, C. Martoni, S. Prakash, Artificial cell microcapsule for oral delivery of live bacterial cells for therapy: design, preparation, and in-vitro characterization, J. Pharm. Pharm. Sci., 7 (2004) 315-324.

[137] J. Lin, W. Yu, X. Liu, H. Xie, W. Wang, X. Ma, In vitro and in vivo characterization of alginatechitosan-alginate artificial microcapsules for therapeutic oral delivery of live bacterial cells, J. Biosci. Bioeng., 105 (2008) 660-665. doi: 10.1263/jbb.105.660.

[138] C. Le-Tien, M. Millette, M.A. Mateescu, M. Lacroix, Modified alginate and chitosan for lactic acid bacteria immobilization, Biotechnol. Appl. Biochem., 39 (2004) 347-354. doi: 10.1042/BA20030158.

[139] C. Le Tien, M. Lacroix, P. Ispas-Szabo, M.-A. Mateescu, N-acylated chitosan: hydrophobic matrices for controlled drug release, J. Control. Release, 93 (2003) 1-13. https://doi.org/10.1016/S01683659(03)00327-4.

[140] N. Kitabatake, Y.-I. Kinekawa, Digestibility of bovine milk whey protein and $\beta$-lactoglobulin in vitro and in vivo, J. Agric. Food Chem., 46 (1998) 4917-4923. https://doi.org/10.1021/jf9710903.

[ 141] G.K. Gbassi, T. Vandamme, S. Ennahar, E. Marchioni, Microencapsulation of Lactobacillus plantarum spp in an alginate matrix coated with whey proteins, Int. J. Food Microbiol., 129 (2009) 103 105. https://doi.org/10.1016/j.ijfoodmicro.2008.11.012.

[142] K. Kailasapathy, Survival of free and encapsulated probiotic bacteria and their effect on the sensory properties of yoghurt, LWT-Food Sci. Technol., 39 (2006) 1221-1227. https://doi.org/10.1016/j.lwt.2005.07.013.

[143] L. Mei, F. He, R.-Q. Zhou, C.-D. Wu, R. Liang, R. Xie, X.-J. Ju, W. Wang, L.-Y. Chu, Novel intestinal-targeted Ca-alginate-based carrier for $\mathrm{pH}$-responsive protection and release of lactic acid bacteria, ACS appl. Mater. Inter., 6 (2014) 5962-5970. https://doi.org/10.1021/am501011j.

[144] L.L. Schramm, E.N. Stasiuk, D.G. Marangoni, 2 Surfactants and their applications, Annu. Rep. Section" C"(Physical Chemistry), 99 (2003) 3-48. https://doi.org/10.1039/B208499F.

[145] . Chen, Y. Cao, L.R. Ferguson, Q. Shu, S. Garg, Flow cytometric assessment of the protectants for enhanced in vitro survival of probiotic lactic acid bacteria through simulated human gastro-intestinal stresses, Appl. Microbiol. Biotechnol., 95 (2012) 345-356. doi: 10.1007/s00253-012-4030-3.

[146] H.A. Albadran, A. Chatzifragkou, V.V. Khutoryanskiy, D. Charalampopoulos, Development of surfactant-coated alginate capsules containing Lactobacillus plantarum, Food hydrocoll., 82 (2018) 490-499. doi: 10.1016/j.foodhyd.2018.04.035.

[147] J.M. de Barros, T. Scherer, D. Charalampopoulos, V.V. Khutoryanskiy, A.D. Edwards, A laminated polymer film formulation for enteric delivery of live vaccine and probiotic bacteria, J. pharm. Sci., 103 (2014) 2022-2032. doi: 10.1002/jps.23997.

[148] J.M. de Barros, T. Lechner, D. Charalampopoulos, V.V. Khutoryanskiy, A.D. Edwards, Enteric coated spheres produced by extrusion/spheronization provide effective gastric protection and efficient release of live therapeutic bacteria, Int. J. Pharm., 493 (2015) 483-494. doi: 10.1016/j.ijpharm.2015.06.051.

[149] A. Dukić-Ott, M. Thommes, J.P. Remon, P. Kleinebudde, C. Vervaet, Production of pellets via extrusion-spheronisation without the incorporation of microcrystalline cellulose: a critical review, Eur. J. Pharm. Biopharm., 71 (2009) 38-46. doi: 10.1016/j.ejpb.2008.08.005.

[150] S. Kolida, G.R. Gibson, Synbiotics in health and disease, Annu. Rev. Food Sci. Technol., 2 (2011) 373-393. doi: 10.1146/annurev-food-022510-133739.

[151] G. Reid, J. Jass, M.T. Sebulsky, J.K. McCormick, Potential uses of probiotics in clinical practice, Clin. Microbiol. Rev., 16 (2003) 658-672. doi: 10.1128/cmr.16.4.658-672.2003.

[152] J. Slavin, Fiber and prebiotics: mechanisms and health benefits, Nutrients, 5 (2013) 1417-1435. doi: $10.3390 /$ nu5041417.

[153] S. Sathyabama, R. Vijayabharathi, Co-encapsulation of probiotics with prebiotics on alginate matrix and its effect on viability in simulated gastric environment, LWT-Food Sci. Technol., 57 (2014) 419-425. doi: 10.1016/j.lwt.2013.12.024.

[154] M. Govender, Y.E. Choonara, S. van Vuuren, P. Kumar, L.C. du Toit, V. Pillay, A gastroresistant ovalbumin bi-layered mini-tablet-in-tablet system for the delivery of $\mathrm{L}$ actobacillus acidophilus probiotic to simulated human intestinal and colon conditions, J. Pharm. Pharmacol., 67 (2015) 939-950. doi: 10.1111/jphp.12389. 
[155] R.F. Fakhrullin, A.I. Zamaleeva, R.T. Minullina, S.A. Konnova, V.N. Paunov, Cyborg cells: functionalisation of living cells with polymers and nanomaterials, Chem. Soc. Rev., 41 (2012) 41894206. https://doi.org/10.1039/C2CS15264A.

[156] A.J. Priya, S. Vijayalakshmi, A.M. Raichur, Enhanced survival of probiotic Lactobacillus acidophilus by encapsulation with nanostructured polyelectrolyte layers through layer-by-layer approach, J. Agric. Food Chem., 59 (2011) 11838-11845. doi: 10.1021/jf203378s.

[157] M.B. Thomas, M. Vaidyanathan, K. Radhakrishnan, A.M. Raichur, Enhanced viability of probiotic Saccharomyces boulardii encapsulated by layer-by-layer approach in $\mathrm{pH}$ responsive chitosandextran sulfate polyelectrolytes, J. Food Eng., $136 \quad$ (2014) 1-8. https://doi.org/10.1016/j.jfoodeng.2014.03.015.

[158] S. Klayraung, H. Viernstein, S. Okonogi, Development of tablets containing probiotics: Effects of formulation and processing parameters on bacterial viability, Int. J. Pharm., 370 (2009) 54-60. doi: 10.1016/j.ijpharm.2008.11.004.

[159] E. Chan, Z. Zhang, Encapsulation of probiotic bacteria Lactobacillus acidophilus by direct compression, Food Bioprod. Process., 80 (2002) 78-82. https://doi.org/10.1205/09603080252938708.

[160] M. Stadler, H. Viernstein, Optimization of a formulation containing viable lactic acid bacteria, Int. J. Pharm., 256 (2003) 117-122. doi: 10.1016/s0378-5173(03)00068-1.

[161] C. Calinescu, J. Mulhbacher, É. Nadeau, J.M. Fairbrother, M.A. Mateescu, Carboxymethyl high amylose starch (CM-HAS) as excipient for Escherichia coli oral formulations, Eur. J. Pharm. Biopharm., 60 (2005) 53-60. doi: 10.1016/j.ejpb.2004.12.006.

[162] C. Calinescu, M.A. Mateescu, Carboxymethyl high amylose starch: Chitosan self-stabilized matrix for probiotic colon delivery, Eur. J. Pharm. Biopharm., 70 (2008) 582-589. doi: 10.1016/j.ejpb.2008.06.006.

[163] H. Wu, J. Fan, X. Qin, G. Zhang, Thermal radiative properties of electrospun superfine fibrous PVA films, Mater. lett., 62 (2008) 828-831. https://doi.org/10.1016/j.matlet.2007.06.080.

[ 164] S.p. Zupančič, T. Rijavec, A. Lapanje, M. Petelin, J. Kristl, P. Kocbek, Nanofibers with incorporated autochthonous bacteria as potential probiotics for local treatment of periodontal disease, Biomacromolecules, 19 (2018) 4299-4306. doi: 10.1021/acs.biomac.8b01181.

[165] A.L. Yarin, E. Zussman, J. Wendorff, A. Greiner, Material encapsulation and transport in coreshell micro/nanofibers, polymer and carbon nanotubes and micro/nanochannels, J. Mater. Chem., 17 (2007) 2585-2599. https://doi.org/10.1039/B618508H.

[166] A. Greiner, J. Wendorff, A. Yarin, E. Zussman, Biohybrid nanosystems with polymer nanofibers and nanotubes, Appl. Microbiol. Biotechnol., 71 (2006) 387-393. doi: 10.1007/s00253-006-0356-z.

[167] G.K. Gbassi, T. Vandamme, S. Ennahar, E. Marchioni, Microencapsulation of Lactobacillus plantarum spp in an alginate matrix coated with whey proteins, Int. J. Food. Microbiol., 129 (2009) 103-105. doi: 10.1016/j.ijfoodmicro.2008.11.012.

[168] H. Chen, W. Ouyang, Jones, M, T. Haque, B. Lawuyi, S. Prakash, In-vitro analysis of APA microcapsules for oral delivery of live bacterial cells, J. Microencaps., 22 (2005) 539-547. https://doi.org/10.1080/02652040500162162.

[169] M.T. Cook, G. Tzortzis, D. Charalampopoulos, V.V. Khutoryanskiy, Microencapsulation of a synbiotic into PLGA/alginate multiparticulate gels, Int. J. Pharm., 466 (2014) 400-408. doi: 10.1016/j.ijpharm.2014.03.034.

[170] C.B. Fritzen-Freire, E.S. Prudêncio, R.D. Amboni, S.S. Pinto, A.N. Negrão-Murakami, F.S. Murakami, Microencapsulation of bifidobacteria by spray drying in the presence of prebiotics, Food Res. Int., 45 (2012) 306-312. doi: 10.1016/j.foodres.2011.09.020.

[171] M.J.M. Villena, F. Lara-Villoslada, M.A.R. Martinez, M.E.M. Hernandez, Development of gastro-resistant tablets for the protection and intestinal delivery of Lactobacillus fermentum CECT 5716, Int. J. Pharm., 487 (2015) 314-319. doi: 10.1016/j.ijpharm.2015.03.078.

[172] A.C. Khorasani, S.A. Shojaosadati, Bacterial nanocellulose-pectin bionanocomposites as prebiotics against drying and gastrointestinal condition, Int. J. Biol. Macromol., 83 (2016) 9-18. doi: 10.1016/j.ijbiomac.2015.11.041.

[173] A. Rao, N. Shiwnarain, I. Maharaj, Survival of microencapsulated Bifidobacterium pseudolongum in simulated gastric and intestinal juices, Canadian Institute of Food Science and Technology Journal, 22 (1989) 345-349. 
[174] D. Guerin, J.-C. Vuillemard, M. Subirade, Protection of bifidobacteria encapsulated in polysaccharide-protein gel beads against gastric juice and bile, J. Food Prot., 66 (2003) 2076-2084. doi: 10.4315/0362-028x-66.11.2076.

[175] H. Chen, W. Ouyang, M. Jones, T. Metz, C. Martoni, T. Haque, R. Cohen, B. Lawuyi, S. Prakash, Preparation and characterization of novel polymeric microcapsules for live cell encapsulation and therapy, Cell. Biochem. Biophys., 47 (2007) 159-167. https://doi.org/10.1385/CBB:47:1:159.

[176] W. Ding, N.P. Shah, Effect of various encapsulating materials on the stability of probiotic bacteria, J. Food Sci., 74 (2009) M100-M107. doi: 10.1111/j.1750-3841.2009.01067.x.

[177] M. Stadler, H. Viernstein, Optimization of a formulation containing viable lactic acid bacteria, Int. J. Pharm., 256 (2003) 117-122. doi: 10.1016/s0378-5173(03)00068-1.

[178] S. Prakash, A.M. Urbanska, Colon-targeted delivery of live bacterial cell biotherapeutics including microencapsulated live bacterial cells, Biol. targets ther., 2 (2008) 355. doi: $10.2147 / \mathrm{btt} . \mathrm{s} 2372$.

[179] M. Chourasia, S. Jain, Pharmaceutical approaches to colon targeted drug delivery systems, $J$ Pharm Pharm Sci, 6 (2003) 33-66.

[180] G. Van Den Mooter, B. Maris, C. Samyn, P. Augustijns, R. Kinget, Use of azo polymers for colon-specific drug delivery, J. Pharm. Sci., 86 (1997) 1321-1327. https://doi.org/10.1021/js9702630.

[181] M. Naeem, W. Kim, J. Cao, Y. Jung, J.-W. Yoo, Enzyme/pH dual sensitive polymeric nanoparticles for targeted drug delivery to the inflamed colon, Colloids Surf. B: Biointerfaces., 123 (2014) 271-278. doi: 10.1016/j.colsurfb.2014.09.026.

[182] M. Naeem, M. Choi, J. Cao, Y. Lee, M. Ikram, S. Yoon, J. Lee, H.R. Moon, M.-S. Kim, Y. Jung, Colon-targeted delivery of budesonide using dual $\mathrm{pH}$-and time-dependent polymeric nanoparticles for colitis therapy, Drug Des. Devel. ther., 9 (2015) 3789. doi: 10.2147/DDDT.S88672.

[183] S.A. Misal, K.R. Gawai, Azoreductase: a key player of xenobiotic metabolism, Bioresour. Bioprocess., 5 (2018) 1-9.

[184] T. Ooi, T. Shibata, R. Sato, H. Ohno, S. Kinoshita, T.L. Thuoc, S. Taguchi, An azoreductase, aerobic NADH-dependent flavoprotein discovered from Bacillus sp.: functional expression and enzymatic characterization, Appl. Microbiol. Biotechnol., 75 (2007) 377-386. doi: 10.1007/s00253006-0836-1.

[185] T. Yamaoka, Y. Makita, H. Sasatani, S.-I. Kim, Y. Kimura, Linear type azo-containing polyurethane as drug-coating material for colon-specific delivery: its properties, degradation behavior, and utilization for drug formulation, J. Control. Release., 66 (2000) 187-197. doi: 10.1016/s01683659(99)00270-9.

[186] J. Rao, A. Khan, Enzyme sensitive synthetic polymer micelles based on the azobenzene motif, J. Am. Chem. Soc., 135 (2013) 14056-14059. https://doi.org/10.1021/ja407514z.

[187] N. Singh, R. Khanna, Colon targeted drug delivery systems-A Potential Approach, The Pharma Innovation, 1 (2012) 40-47.

[188] Y. Qiu, K. Park, Environment-sensitive hydrogels for drug delivery, Adv. Drug Del. Rev., 53 (2001) 321-339. doi: 10.1016/s0169-409x(01)00203-4.

[189] C. Lautenschläger, C. Schmidt, D. Fischer, A. Stallmach, Drug delivery strategies in the therapy of inflammatory bowel disease, Adv. Drug Del. Rev., 71 (2014) 58-76. doi: 10.1016/j.addr.2013.10.001.

[190] A.A. D'Souza, P.V. Devarajan, Bioenhanced oral curcumin nanoparticles: Role of carbohydrates, Carbohydrate. Polym., 136 (2016) 1251-1258. doi: 10.1016/j.carbpol.2015.10.021.

[191] T. Minko, Drug targeting to the colon with lectins and neoglycoconjugates, Adv. Drug Del. Rev., 56 (2004) 491-509. doi: 10.1016/j.addr.2003.10.017.

[192] G. Yilmaz, C.R. Becer, Glyconanoparticles and their interactions with lectins, Polym. Chem., 6 (2015) 5503-5514. https://doi.org/10.1039/C5PY00089K.

[193] P.W. O'Toole, J.R. Marchesi, C. Hill, Next-generation probiotics: the spectrum from probiotics to live biotherapeutics, Nat. Microbiol., 2 (2017) 17057. doi: 10.1038/nmicrobiol.2017.57.

[194] C.-J. Chang, T.-L. Lin, Y.-L. Tsai, T.-R. Wu, W.-F. Lai, C.-C. Lu, H.-C. Lai, Next generation probiotics in disease amelioration, J. Food Drug Anal., 27 (2019) 615-622. doi: 10.1016/j.jfda.2018.12.011.

[195] N. Zmora, G. Zilberman-Schapira, J. Suez, U. Mor, M. Dori-Bachash, S. Bashiardes, E. Kotler, M. Zur, D. Regev-Lehavi, R.B.-Z. Brik, Personalized gut mucosal colonization resistance to empiric 
probiotics is associated with unique host and microbiome features, Cell, 174 (2018) 1388-1405. e1321. https://doi.org/10.1016/j.cell.2018.08.041.

[196] A.C. Anselmo, K.J. McHugh, J. Webster, R. Langer, A. Jaklenec, Layer-by-layer encapsulation of probiotics for delivery to the microbiome, Adv. Mater., 28 (2016) 9486-9490. https://doi.org/10.1002/adma.201603270.

[197] Z.J. Mays, T.C. Chappell, N.U. Nair, Quantifying and engineering mucus adhesion of probiotics, ACS Synth. Biol., 9 (2020) 356-367. https://doi.org/10.1021/acssynbio.9b00356.

[ 198] E.G. Zoetendal, A. von Wright, T. Vilpponen-Salmela, K. Ben-Amor, A.D. Akkermans, W.M. de Vos, Mucosa-associated bacteria in the human gastrointestinal tract are uniformly distributed along the colon and differ from the community recovered from feces, Appl. Environ. Microbiol., 68 (2002) 3401-3407. doi: 10.1128/aem.68.7.3401-3407.2002.

[199] P. Panigrahi, S. Parida, N.C. Nanda, R. Satpathy, L. Pradhan, D.S. Chandel, L. Baccaglini, A. Mohapatra, S.S. Mohapatra, P.R. Misra, A randomized synbiotic trial to prevent sepsis among infants in rural India, Nature, 548 (2017) 407-412. doi: 10.1038/nature23480.

[200] H. Jijon, J. Backer, H. Diaz, H. Yeung, D. Thiel, C. McKaigney, C. De Simone, K. Madsen, DNA from probiotic bacteria modulates murine and human epithelial and immune function, Gastroenterology, 126 (2004) 1358-1373. doi: 10.1053/j.gastro.2004.02.003.

[201] B. Barletta, G. Rossi, E. Schiavi, C. Butteroni, S. Corinti, M. Boirivant, G. Di Felice, Probiotic VSL\# 3-induced TGF- $\beta$ ameliorates food allergy inflammation in a mouse model of peanut sensitization through the induction of regulatory T cells in the gut mucosa, Mol. Nutr. Food Res., 57 (2013) 22332244. doi: $10.1002 / \mathrm{mnfr} .201300028$.

[202] P. Gionchetti, F. Rizzello, U. Helwig, A. Venturi, K.M. Lammers, P. Brigidi, B. Vitali, G. Poggioli, M. Miglioli, M. Campieri, Prophylaxis of pouchitis onset with probiotic therapy: a doubleblind, placebo-controlled trial, Gastroenterology, 124 (2003) 1202-1209. doi: 10.1016/s00165085(03)00171-9.

[203] J. Shen, Z.-X. Zuo, A.-P. Mao, Effect of probiotics on inducing remission and maintaining therapy in ulcerative colitis, Crohn's disease, and pouchitis: meta-analysis of randomized controlled trials, Inflamm. Bowel Dis., 20 (2014) 21-35. doi: 10.1097/01.MIB.0000437495.30052.be.

[204] E.-D. Yu, Z. Shao, B. Shen, Pouchitis, World J. Gastroentero., 13 (2007) 5598-5604. doi: 10.3748/wjg.v13.i42.5598. 